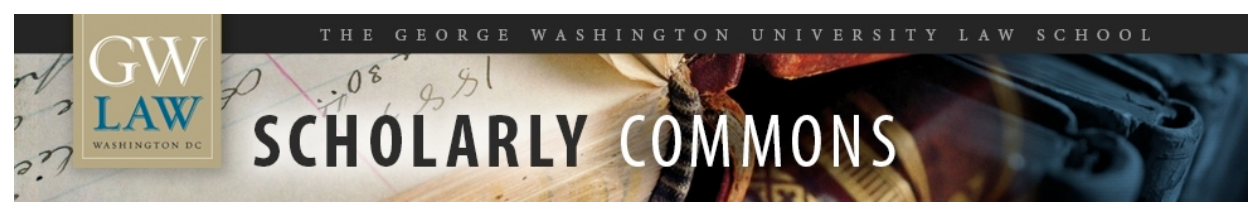

\title{
How the Creation of Appellate Courts in England and the United States Limited Judicial Comment on Evidence to the Jury
}

\author{
Renée Lettow Lerner \\ George Washington University Law School, rlerner@law.gwu.edu
}

Follow this and additional works at: https://scholarship.law.gwu.edu/faculty_publications

Part of the Law Commons

\begin{abstract}
Recommended Citation
Lerner, Renee Lettow, How the Creation of Appellate Courts in England and the United States Limited Judicial Comment on Evidence to the Jury (2016). 40 J. Legal Prof. 215 (2016).; GWU Law School Public Law Research Paper No. 2016-20; GWU Legal Studies Research Paper No. 2016-20. Available at SSRN: http://ssrn.com/abstract= http://ssrn.com/abstract=2797310
\end{abstract}

This Article is brought to you for free and open access by the Faculty Scholarship at Scholarly Commons. It has been accepted for inclusion in GW Law Faculty Publications \& Other Works by an authorized administrator of Scholarly Commons. For more information, please contact spagel@law.gwu.edu. 


\title{
HOW THE CREATION OF APPELlATE COURTS IN ENGLAND AND THE UNITED STATES LIMITED JUDICIAL COMMENT ON EVIDENCE TO THE JURY
}

\author{
By Renée Lettow Lerner*
}

\begin{abstract}
The practice of judicial comment on the evidence has traditionally been the main form of jury control. Previous scholarly work has focused on the loss of the power in state courts, and has attributed the decline of judicial comment to a strict separation of functions between judge and jury and to regional differences in legal culture. This article examines two jurisdictions in which the power of comment long remained strong, at least in theory: the High Court of England, with its predecessors, and the federal courts in the United States. In both jurisdictions, judicial power to comment has been limited and in practice reduced, in the federal courts severely. The article reveals that this limitation developed with the advent of courts of appeal with separate personnel and especially of appeals in criminal cases.

Lack of appeal, or limited appeal, has been a distinctive trait of common law systems, particularly in criminal cases. There was no appeal as of right in criminal cases until 1907 in England, and 1889 in the federal courts. In the federal system, the early movements to allow appeals in criminal cases and to limit judicial comment on evidence focused on controlling one judge: Isaac Parker, U.S. District Judge for the Western District of Arkansas, who presided over more than 100 trials for capital crimes occurring in the Indian Territory from 1875 to 1896.

The article suggests that the most important traditional method of jury control-judicial comment on evidence - has proved to be unworkable in the judicial culture of the United States and difficult in England. Jury trial long impeded appeals, but when they arrived, appellate courts limited the

\footnotetext{
* Professor of Law, George Washington University Law School, rlerner@law.gwu.edu. I thank Gregory Ablavsky, Bradford Clark, George Fisher, Lawrence Friedman, Robert Gordon, Emily Hammond, John Harrison, Amalia Kessler, John Langbein, Maeva Marcus, Alan Morrison, Cynthia participants in the Stanford Law and Humanities Workshop, the University of Virginia Legal History Workshop, and the American Society for Legal History annual meeting for their helpful comments and suggestions.
} Nicoletti, James Oldham, Saikrishna Prakash, Jonathan Rose, Sarah Seo, Frederick Schauer, and
\end{abstract}


discretion of trial judges. In doing so, appellate courts focused on procedures rather than the merits of a case. In contrast, appeals in legal systems of the Continent of Europe are thorough and focused on the merits. 
I. INTRODUCTION

II. RATIONALES FOR JUDICIAL COMMENT ON EVIDENCE AND LACK

OF APPEAL

III. ENGLAND .226

A. Structure of the Courts Through the Mid-Nineteenth

Century and the Practice of Judicial Comment on

Evidence .226

B. The Elimination of Civil Jury Trial in England

C. Comment in Criminal Cases.

D. Establishment of Trial Courts and Courts of Appeal with Separate Personnel.

E. The Special Situation of Criminal Appeals and Comment on Evidence .239

IV. Federal Courts IN THE UnITED STATES.......................................242

A. The Federal Courts to the Late Nineteenth Century .242

1. Organization

2. Judicial Comment: Broad Discretion in the First

Hundred Years .249

3. The Effects of Differing State Practices .251

B. Review of Capital Cases in the Supreme Court: 1889 .254

1. Judge Isaac Parker and the Origins of the 1889 Act... .254 
2. Change in Review of Judicial Comment

C. Creation of an Intermediate Court of Appeals: 1891

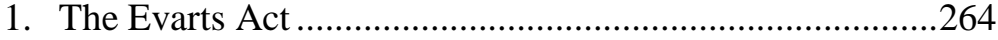

2. Later Cases in the Supreme Court Concerning

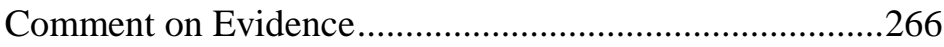

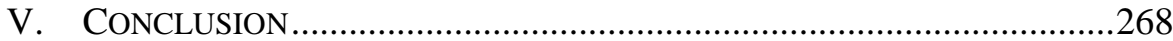




\section{INTRODUCTION}

The practice of judicial comment on the evidence has traditionally been the main form of jury control. ${ }^{1}$ The practice concerns three features typical of common law systems: the use of lay decision-makers as exclusive judges of fact, the use of a single professional judge in the first instance, and lack of thorough appeals on the merits. This article examines two jurisdictions in which the power of comment long remained strong, at least in theory: the High Court of England, with its predecessors, and the federal courts in the United States. In both of these jurisdictions, trial judges have secure tenure and considerable prestige. In both jurisdictions, judicial power to comment has been limited and in practice reduced, in the federal courts severely. The article reveals that this limitation developed with the advent of courts of appeal with separate personnel. Appeals in criminal cases, especially, led to limitations on judicial comment on evidence.

Lack of appeal, or limited appeal, has been a distinctive trait of common law systems, particularly in criminal cases. There was no appeal as of right whatsoever in criminal cases until 1907 in England $^{2}$ and 1889 in the federal courts. ${ }^{3}$ In England, the development of a court of criminal appeal with a personnel mostly separate from that of the trial courts did not occur until $1966 .{ }^{4}$ In the federal system, the movements to allow appeals in criminal cases and to limit judicial comment on evidence focused initially on controlling one judge: Isaac Parker, U.S. District Judge for the Western District of Arkansas, who presided over more than 100 trials for capital crimes occurring in the Indian Territory from 1875 to 1896 . The opinions of the Supreme Court reversing convictions for Judge Parker's comments on evidence began a long process of limiting judicial comment in the federal courts.

The article suggests that the most important traditional method of jury control-judicial comment on evidence-has proved to be unworkable in the judicial culture of the United States and difficult in England. Jury trial for centuries impeded appeals, but when they developed, appellate courts limited the discretion of trial judges. In doing so, appellate courts focused on procedures rather than the merits of a case. In contrast, appeals in Continental European legal systems o are thorough and focused on the merits.

1. John H. Langbein, Renée Lettow LeRner \& Bruce P. SMith, History of the Common LAW: THE DEVELOPMENT OF ANGLO-AMERICAN LEgAL INSTITUTIONS 431-33 (2009).

2. Criminal Appeal Act, 1907, 7 Edw. VII, c. 23.

3. Act of Feb. 6, 1889, c. 113, 25 STAT. 655.

4. Criminal Appeal Act, 1966; see also D.A. Thomas, The Criminal Appeal Act 1966, 30 M.L.R. 64, 64-65 (1967). 


\section{RATIONALES FOR JUDICIAL COMMENT ON EVIDENCE AND LACK OF APPEAL}

Adjudication by ordinary laypersons has long raised concerns, and these concerns grew more acute as common law systems became more adversarial. Judges and commentators have argued that lay jurors are apt to be confused by conflicting evidence, especially in complicated cases. ${ }^{5}$ Jurors also may be swayed by the superior rhetorical skill of counsel for one side rather than the merits of a case. ${ }^{6}$

To help correct these problems, a common law judge traditionally has the power to sum up the evidence at the end of trial and to comment on the evidence to the jury. The rationales that have long been given for these practices, and still are given today, are to prevent juror confusion and to counteract the partisanship of counsel. ${ }^{7}$ Tocqueville believed that the judge's ability to comment on evidence was crucial to the proper functioning of juries. He stressed how important it was that the judge help to guide the jury: "It is he who unravels the various arguments they are finding it so hard to remember and takes them by the hand to guide them through procedural intricacies." $\mathrm{He}$ acts as "a disinterested arbitrator between the litigants' passions." English treatise-writer Joseph Chitty, whose General Practice went through many American editions in the early nineteenth century and was a popular reference for American lawyers, believed judicial comment on evidence was necessary to counter the power of strong advocacy: "without this assistance from the learned judge, few juries would, in a contested cause, be able to come to an unanimous opinion, being frequently left in a state of great perplexity by the influence of the speeches of the contending leaders." Judge Thomas Ruffin of the North Carolina Supreme Court also focused on the danger of powerful advocates. In an 1830 opinion, he explained that "after the able and ingenious, but interested and partial arguments of Counsel," justice would be better served by the judge following with "his own calm, discreet,

5. Jack B. Weinstein, The Power and Duty of Federal Judges to Marshall and Comment on the Evidence in Jury Trials and Some Suggestions on Charging Juries, 118 F.R.D. 161, 166 (1988); see also Renée Lettow Lerner, The Failure of Originalism in Preserving Constitutional Rights to Civil Jury Trial, 22 WM. \& MARY BILL RTS. J. 811, 849-50 (2014).

6. See, e.g., Weinstein, supra note 5, at 166.

7. Id. For a modern criticism of the judicial power to comment, see Stephen A. Saltzburg, The Unnecessarily Expanding Role of the American Trial Judge, 64 VA. L. REV. 1, 34-46 (1978) (arguing that judicial comment on evidence threatens the independence of the jury and the adversarial system)

8. 1 AleXis DE TOCQueville, Democracy In AMERICA 275 (J.P. Mayer ed., George Lawrence trans., HarperCollins 1988) (1850).

9. TOCQUEVILLE, supra note 8.

10. 3 Joseph ChitTy, The Practice of LaW in All Its Departments 913 (1836). 
sensible and impartial summary of the case, including both law and fact."11 The judge should "aid[] the jury[] by rescuing the case from the false glosses of powerful advocates.",

A problem with these practices of judicial summing up and comment is that in common law systems, usually only one professional judge hears a trial. That judge may be biased, lazy, corrupt, or incompetent. No judicial colleagues are present in courts of the first instance to help correct such errors. The judicial summing up or comments on the evidence may therefore mislead the jury and cause or contribute to an improper verdict.

Misleading judicial summing up or comment on the evidence might be corrected on appeal. But appeal has long been a weakness of common law systems. Jury verdicts do not lend themselves to appellate review. As a group of laypersons inexperienced in the law and evaluation of facts, a jury is not required to give reasons for what it does. A jury speaks unanimously, and mysteriously, like an oracle. One cannot subject the oracle at Delphi to appellate review. The common law, when it has permitted review at all, focuses on inputs, not outputs: whether particular evidence or judicial instructions should have gone to a jury, rather than the merits of the jury's decision.

In the eighteenth century, common law courts did not have courts of appeal with separate personnel; judges who presided over trials sat together to correct error. ${ }^{13}$ There was therefore the danger of less thorough review. In civil cases, appeals were often hampered by technical restrictions. (Throughout this article, I refer to various methods of review as "appeal," even though technically the methods were writ of error, bill of exceptions, and other procedures.) In criminal cases, there was no review as of right at all until very late: 1889 in the U.S. federal courts in capital cases, ${ }^{14}$ and

11. State v. Moses, 13 N.C. 452, 458 (1830). Ruffin came from the Virginia tidewater elite and had studied, like his fellow Virginian James Madison, at the College of New Jersey (later Princeton). Timothy S. Huebner, The Southern Judicial Tradition: State Judges and Sectional DisTinCTIVENESS, 1790-1890, 131-35 (Kermit Hall ed.1999).

12. State v. Moses, 13 N.C. at 462. The judge was well-suited to do this, in Ruffin's view, because typically he was "upright, learned, and discreet" and "habituated to the investigation of complicated masses of testimony, often contradictory, and often apparently so but really reconcilable." Id. Elucidations from such a judge would be "of infinite utility to a conscientious jury in arriving at just conclusions." Id. at 458 .

13. LANGBEIN, LERNER \& SMITH, supra note 1, at 248, 256. The system of review in common law courts was complicated, with King's Bench exercising a special supervisory role. See J.H. BAKER, AN INTRODUCTION TO ENGLiSh LEGAL HISTORY 82-85, 135-54, 521-23 (4th ed. 2005); ROSCOE POUND, ApPellate Procedure in Civil CASes 57-60 (1941). American colonists associated the word "appeal" with equity and the prerogative courts. Mary S. Bilder, The Origin of the Appeal in America, 48 HASTings L.J. 913, 951-61 (1997).

14. Act of Feb. 6, 1889, c. 113, 25 STAT. 655. 
1891 in other cases, ${ }^{15}$ and 1907 in England. ${ }^{16}$ These appeals were only for convictions; because of the double jeopardy rule, a verdict of acquittal was final. As will be seen, an important objection to appeals in criminal cases was the delay and uncertainty of outcome. Judges in both England and the United States protested that appeals in criminal cases would reduce the certainty and swiftness of punishment needed for effective deterrence.

The common law courts tried to justify, or compensate for, the lack of appeal in various ways. These included:

- The unanimity of the jury. Twelve of one's peers had to agree on the verdict.

- Comment on evidence by the trial judge to try to prevent the jury from going astray.

- The prestige of the trial bench. In England, the highest common law judges traveled the circuits and served as trial judges. ${ }^{17}$ In the federal courts, Supreme Court justices rode circuit around the country and served as trial judges in the most important cases. ${ }^{18}$

- The use of panels of judges in the first instance. This was not so much done in England except in treason cases, ${ }^{19}$ but it was relatively common in the United States. At first, the main federal trial courts, called the circuit courts, were set up to use three or two trial judges, at least one of whom was a Supreme Court justice. ${ }^{20}$ Various states used a similar model. $^{21}$

- Executive clemency, following a criminal conviction. ${ }^{22}$

If review did occur and error was found, typically the remedy was the time-consuming and expensive new trial. The sources of error that could trigger a new trial grew over time, as judges converted what previously had been questions of fact into questions of law through ever-more elaborate jury instructions. ${ }^{23}$ The expense and delay of new trials encouraged

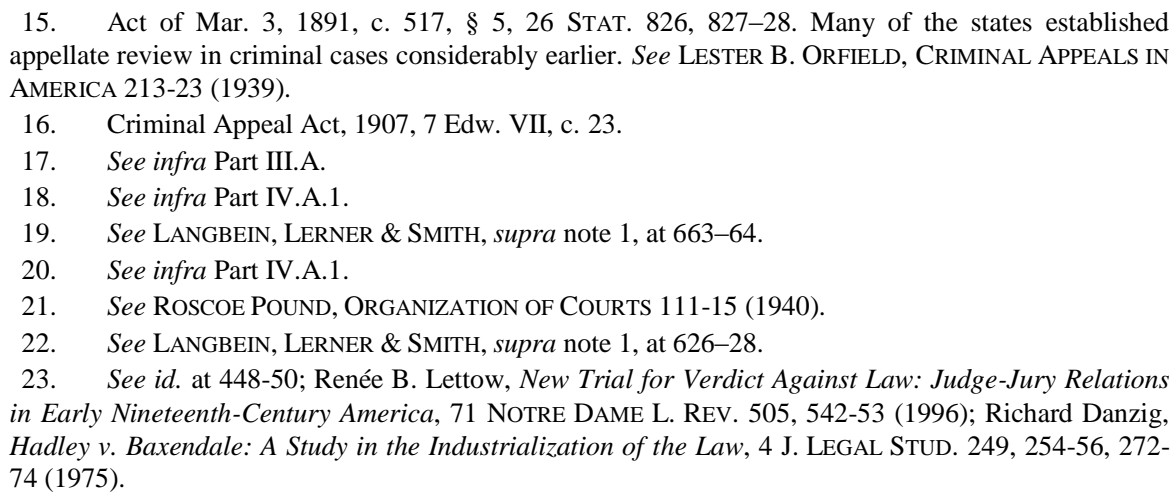


judicial comment on the evidence and even stronger related forms of jury control such as directed verdict. ${ }^{24}$ The lack of thorough appeal and efficient remedy encouraged a procedure for jury control that in turn sometimes needed correction. Judges focused ever more on procedures and less on merit. This is a cycle familiar to historians of the common law.

Contrast this situation with the nonadversarial systems of the Continent of Europe. The civil courts of Germany can serve as an example. In important cases, there may be a panel of judges in the first instance. ${ }^{25}$ The first appeal is to a court with separate personnel and is thorough on the merits. The standard is de novo review of both findings of fact and conclusions of law. ${ }^{26}$ Courts of appeal may find facts and enter a new judgment without remanding to the court below. ${ }^{27}$

Gradually, the legal systems of the common law world began to correct their deficiencies concerning appeal. They slowly moved closer to the Continental model. The common law systems created courts of appeal with separate personnel and reduced technical restrictions - and eliminated some outright prohibitions - on appeals. The process is not complete; there is still deference to the court of first instance respecting factual findings, and cases are often remanded for new trial and other proceedings. Appeals, however, became more regular and thorough.

The difficulty was that the common law systems retained the use of lay decision makers, the adversarial system, and single judges of the first instance. Appellate courts began to curtail the power of the trial judge over the jury and second-guessed judicial comments. As has been seen, judges and commentators have believed judicial comments were necessary to prevent confusion of lay jurors and improper influence of advocates. Because of more thorough appeals, trial judges increasingly refrained from thorough summing-up or comments, and juries were left to cope with the evidence and arguments of counsel without guidance. The trial judge operated as less of a check on the adversarial system.

Previous studies of the history of comment on evidence have focused on the loss of the power in state courts. Kenneth Krasity emphasized mainly the period from 1835 to 1860 and attributed the loss of the power in many states to a growing importance of separation of functions between

24. Renée Lettow Lerner, The Rise of Directed Verdict: Jury Power in Civil Cases Before the Federal Rules of 1938, 81 GEO. WASH. L. REV. 448, 459-60, 478-93 (2013) [hereinafter Lerner, Directed Verdict].

25. John H. Langbein, The German Advantage in Civil Procedure, 52 U. CHI. L. REV. 823, 850-51 n.94 (1985).

26. Langbein, supra note 25 , at $855-57$.

27. Id. at 857 . 
judge and jury. ${ }^{28}$ In an earlier article, I stressed regional differences and highlighted the distinctive legal culture of the South and West, with its aggressive bar. ${ }^{29}$ Scholars have observed that the power of federal courts to comment on evidence was considerably stronger than that of many state courts. ${ }^{30}$

This article emphasizes the development of courts of appeal with separate personnel in England and the federal courts. In both jurisdictions, this change was largely complete in the late nineteenth century. Trial judges lost prestige relative to appellate judges, and their powers to comment were limited. The gap between trial and appellate judges - and limitations on the power to comment-was more noticeable in the federal courts than in England. In both English and federal courts, the most dramatic limitations in the power to comment came after the development of appeals in criminal cases.

In Part III, the article describes the strong judicial power to comment in England in the eighteenth century. The structure of English courts at the time-with trial judges reviewing cases-aided this power. As the adversarial system grew stronger, especially after 1836 when defense counsel in criminal cases gained the ability to make arguments to the jury, ${ }^{31}$ the trial judges' summing up was viewed as more pro-prosecution than it had been formerly.

With the Judicature Acts of 1873-1875, ${ }^{32}$ England created appellate courts with largely separate personnel from those of the trial courts. However, the prestige of the trial bench remained strong, and its tenure is secure. Nearly all appellate judges in England were trial judges for a substantial period; England uses a promotional model. England has virtually eliminated jury trial for civil cases. In criminal cases, appeal as of right for convictions was not permitted until $1907 .{ }^{33}$ Even then, the Court of Criminal Appeal was at first staffed exclusively with trial judges. After 1966, the appellate court used largely separate personnel, ${ }^{34}$ and restrictions on comment grew more significant. English judges regularly sum up the

28. Kenneth Krasity, The Role of the Judge in Jury Trials: The Elimination of Judicial Evaluation of Fact in American State Courts from 1795 to 1913, 62 U. DET. L. REV. 595, 595-96 (1985).

29. Renée Lettow Lerner, The Transformation of the American Civil Trial: The Silent Judge, 42 WM. \& MARY L. REV. 195, 199-203 (2000).

30. See, e.g., Seymour D. ThOMPSOn, Charging the JuRy 65-66, 68-72 (St. Louis, William H. Stevenson 1880); Ann Woolhandler \& Michael G. Collins, The Article III Jury, 87 VA. L. REV. 587, 645-49 (2001).

31. $6 \& 7$ Will. 4 , c. $114, \S 1$.

32. Supreme Court of Judicature Act, 1873, 36 \& 37 Vict. c. 66; Supreme Court of Judicature Act, 1875,38 \& 39 Vict. c. 77.

33. Criminal Appeal Act 1907, 7 Edw. VII, c. 23.

34. Criminal Appeal Act, 1966; Thomas, supra note 4. 
evidence for the jury, and retain the power to comment on evidence today, although the power is less frequently used.

The article then turns in Part IV to the power to comment on evidence in federal courts in the United States. Because of the circuit system, Supreme Court justices regularly sat as trial judges through the late nineteenth century. During this period the Court put few restrictions on judicial comment on evidence. Indeed, the Court held in many cases that judicial comment on fact was not reviewable at all. ${ }^{35}$ The Court rejected the idea that federal trial courts were bound by state laws and constitutional provisions restricting or prohibiting judicial comment on evidence. By the end of the nineteenth century and into the early twentieth, the Court declared that the phrase "trial by jury" in the U.S. Constitution meant a trial in which a judge had the power to assist the jury with observations on fact. ${ }^{36}$

The rule that the Supreme Court would not review a trial judge's comments on fact changed after the Court began to hear appeals in capital criminal cases in $1889 .{ }^{37}$ The 1889 act was passed in large part to control one judge: Isaac C. Parker, U.S. district judge for the Western District of Arkansas. For many, Judge Parker represented the dangers of immense judicial power concentrated in one person, uncontrolled by review. Judge Parker's district encompassed a large amount of Indian Territory, and there he had jurisdiction over all criminal cases committed by or against a nonIndian. He was determined to create respect for law and order in his unruly district, and he presided over many capital trials and dozens of executions. Until 1889, none of the convictions was subject to appeal.

After 1889, the Supreme Court reviewed almost fifty capital cases from Judge Parker's court and reversed three dozen. ${ }^{38}$ Several of these reversals were significant because of the Court's objections to Parker's comments on fact to the jury. These cases were cited repeatedly in later decisions by the federal courts of appeals reversing convictions because of a trial court's comments on evidence. ${ }^{39}$ The leading modern case on comment on evidence in the federal courts, Quercia v. United States, 289 U.S. 455 (1933), draws heavily on the holdings of the Court's cases reversing Judge Parker.

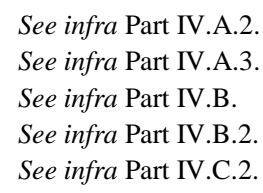




\section{ENGLAND}

\section{A. Structure of the Courts Through the Mid-Nineteenth Century and the Practice of Judicial Comment on Evidence}

At common law in England, every judge was both a trial judge and a member of a collegial court deciding questions of law. The basic structure of the English common law courts was established by the fourteenth century and endured until the Judicature Acts of the 1870s. The structure was not consciously designed, but grew gradually. Each judge of the three common law courts - Common Pleas, King's Bench, and Exchequer - both presided over trials as a single judge and sat with his colleagues to hear initial pleadings and to decide post-trial motions and to enter judgment. When sitting collegially, each court functioned, in effect, as a court of appeal deciding questions of law. ${ }^{40}$

In a civil case, a writ issued out of one of the common law courts at Westminster ordering a sheriff to summon a jury in the county where the events occurred. One of the common law judges - from any of the courtsor an experienced member of the bar then presided over the trial, moving from town to town on a judicial circuit. A party could file post-trial motions, such as a motion for new trial, for the full court to decide, essentially as a court of appeal. This was called the nisi prius system because of the name of the writ informing a sheriff that a jury verdict would be taken in a case. ${ }^{41}$

Matthew Hale, Chief Justice of King's Bench in the late seventeenth century, described the advantages of the circuit system. The judges enjoyed close professional relationships while they sat together at Westminister Hall during the four law terms. This closeness during the terms carried benefits when the judges travelled the circuits. "[B]y this means their judgments and their administrations of common justice carry a consonancy, congruity and uniformity one to another, whereby both the laws and the administrations thereof are preserved from that confusion and disparity that would unavoidably ensue, if the administration was by several incommunicating hands, or by provincial establishments . . . ." Centralized judges travelling out to the provinces maintained uniformity of law and practice. They also served as a direct reminder to the populace all over England of the power of the kingdom's central authority over such crucial matters as serious crime and property rights. As the highest judges

\footnotetext{
40. LANGBEIN, LERNER \& SMITH, supra note 1, at 256.

41. Id. at 123 .

42. Matthew Hale, The History of the Common Law of England 162 (Charles M. Gray, ed. 1971) (1713). This work was published posthumously; Hale died in 1676.
} 
in the land, they carried great prestige wherever they went. The judgments of the courts were to be respected as a result.

The judges of all the common law courts came together to discuss certain issues of law. For civil cases, the judges met in an institution known as Exchequer Chamber. ${ }^{43}$ By the mid-nineteenth century, the sittings of Exchequer Chamber were regularized, occurring after each law term. ${ }^{44}$ By this time, too, the principle of judges not sitting in appeal on cases they had decided below had taken hold. In Exchequer Chamber, therefore, errors and appeals from each common law court were heard only by the judges of the other two courts. $^{45}$

By the eighteenth century, the English bench enjoyed a reputation for competence and had considerable prestige. As there were few common law judges - between a dozen and fifteen at a time, for the entire nation-the power of any one judge was great, and so was his income. Leading members of the bar were eager to become judges. Furthermore, over the course of the eighteenth century, English judges attained a secure position of independence. ${ }^{46}$

English judges routinely gave juries their opinion about the evidence in both civil and criminal cases. ${ }^{47}$ Matthew Hale explained that judicial comment on evidence was a vital aid to jury trial. He wrote that a judge not only directed the jurors on matters of law, but the practice of comment allowed the judge "in Matters of Fact, to give them a great Light and Assistance by his weighing the Evidence before them, and observing where the Question and Knot of the Business lies, and by showing them his Opinion even in Matter of Fact, which is a great Advantage and Light to Lay Men. $"{ }^{48}$ Based on study of a judge's notebooks from the 1750 s, John Langbein concluded that "the judge routinely dominated jury verdicts." 49

43. There was an analogous procedure for criminal cases, the case reserved, initiated solely at the discretion of the trial judge. See infra text accompanying notes 126-128.

44. Act of 1830, 11 Geo. IV \& 1 Will. IV, c. 70. See First Report of the English Judicature Commission, 1869, reprinted in 5 MASs. L.Q. 254, 283 (1920).

45. Act of 1830, 11 Geo. IV \& 1 Will. IV, c. 70; First Report of the English Judicature Commission, supra note 44.

46. LANGBEIN, LERNER \& SMITH, supra note 1, at 655-57.

47. James Oldham, Trial by JuRy: The Seventh Amendment and ANGlo-American SPECIAL JURIES 12-13 (2006) (describing Mansfield's comments to the jury in civil cases) [hereinafter Oldham, TRIAl By JURY]; see also ThOMAS A. GREEN, Verdict ACCORDING TO CONSCIENCE 139 (1985); JoHN H. LANGBEIN, THE ORIGINS OF ADVERSARY CRIMINAL TRIAL 321-22 (2003) [hereinafter LANGBEIN, ORIGINS]; LANGBEIN, LERNER \& SMITH, supra note 1, at 431-36; 1 JAMES OLDHAM, THE MANSFIELD MANUSCRIPTS AND THE GROWTH OF ENGLISH LAW IN THE EIGHTEENTH CENTURY 150, 206 (1992) [hereinafter OlDHAM, MANSFIELD]; John H. Langbein, Historical Foundations of the Law of Evidence: A View from the Ryder Sources, 96 Colum. L. REV. 1168, 1193 (1996) [hereinafter Langbein, Evidence].

48. HALE, supra note 42 , at 164-65.

49. Langbein, Evidence, supra note 47, at 1193. 
"He guided the jurors to his views on the facts and the law, and he seems to have had an informal, conversational relationship with the jurors that allowed him to 'turn up the heat' if he thought the jury was inclining

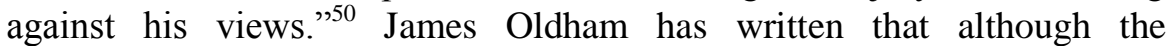
eighteenth-century jury was not legally obliged to follow a judge's direction, "trial judges did frequently direct juries to find for one party or the other, and juries ordinarily complied."

The style and content of judicial comment varied widely. Lord Mansfield, Chief Justice of King's Bench, was praised for presenting complicated cases to juries clearly and succinctly. ${ }^{52}$ Mansfield was known for his use of special juries of merchants in commercial cases. ${ }^{53}$ Together in a sort of partnership, Mansfield and these special jurors furthered the useful development of commercial law, especially insurance law. ${ }^{54}$ Mansfield's successor, Lord Kenyon, held strong religious beliefs and declared them from the bench in certain cases. His comments to juries were especially powerful in actions for criminal conversation, a civil claim by a husband against his wife's lover. According to The Times of London, in one such case in 1794, Howard v. Bingham, Kenyon deplored "the immorality of a libertine age" and told the jurors that one of his chief goals as a judge was to make "the law of the land subservient to the laws of morality and religion." 55 He said he found that "[j] uries co-operate with me" in that endeavor. ${ }^{56}$ Even so, Kenyon could be nuanced in his recommendations concerning damages in cases for criminal conversation. ${ }^{57} \mathrm{He}$ expressed

50. Id.

51. OldhAM, MANSFIELD, supra note 47, at 150. Mansfield told James Boswell that juries followed his direction "except in political causes where they do not at all keep themselves to right and wrong." Id. at 206, (quoting 6 THE PRIVATE PAPERS OF JAMES Boswell FROM MALAhIDE CASTLE 109 (G. Scott \& F.A. Pottle eds. 1928)).

52. OLDHAM, MANSFIELD, supra note 47 , at 87.

53. OLDHAM, TRIAL BY JURY, supra note 47, at 153.

54. Id. at 153-54; JAMES Oldham, ENGLish COMmon LAW IN THE AgE OF MANSFIELD 20-22 (2004). The use of special juries of merchants continued through the mid-nineteenth century. OLDHAM, TRIAL BY JURY, supra note 47, at 154-173; James Oldham, Jury Research in the English Reports in $C D-R O M$, in "THE DEAREST BIRTHRIGHT OF THE PEOPLE OF ENGLAND": THE JURY IN THE History OF THE COMMON LAW 134-44 (John W. Cairns \& Grant McLeod eds., 2002).

55. Law Report, The Times, Mar. 6, 1794, at 2 (reporting on the case of Howard v. Bingham). I owe the references to Kenyon to James Oldham.

56. Id.

57. "Causes of this kind have very different complexions, causes have come before me, where I have thought it incumbent on Juries to discharge plaintiffs with small damages. Causes of this kind have come before me, where I have thought the very cause of action failed, and therefore the plaintiff has been nonsuited. There have also been causes of this sort where Juries have given very large damages." Id. There were occasional protests after Kenyon pressed the jury for large damages. One juror in another criminal conversation case before Lord Kenyon explained in a letter to The Times in 1798 that he had followed Kenyon's instructions and awarded large damages, despite the juror's doubts, only to have the verdict ridiculed afterward. A Juror, Letter to the Rt. Hon. Lord Kenyon, THE TIMES, Mar. 26, 1798 , at 3. 
sympathy for the lovers as well as the husband in the unusual circumstances of Howard v. Bingham, and stated to the jury: "I should give damages, not merely nominal damages, but damages not to a very large amount." 58 The amount claimed was $£ 10,000$; the jury awarded $£ 1,000 .{ }^{59}$ In another case of criminal conversation, Kenyon suggested to the jury that the conduct of the husband, in ignoring his young wife's behavior as "an absolute strumpet, frequenting all the fashionable places of vice and dissipation," should result in a verdict for the defendant. ${ }^{60}$ The jury gave a verdict for the plaintiff for $1 \mathrm{~s} .{ }^{61}$

\section{B. The Elimination of Civil Jury Trial in England}

English judges' power to comment on evidence played an important role in virtually eliminating the civil jury there, a process beginning in the mid-nineteenth century and extending into the twentieth. As Conor Hanly has explained, the English legal profession had confidence that English judges were on the whole impartial and competent. ${ }^{62}$ Members of the English legal profession and others also increasingly criticized jurors as incompetent to decide complicated disputes. ${ }^{63}$ As English judges already dominated juries thanks to judicial powers to sum up and to comment on evidence, ${ }^{64}$ it was a small additional step to eliminate juries and to save the trouble and expense. In 1850, The Times of London declared that in 99 cases out of 100, the verdict turned more on the judge than the jury, and the "mere pantomimical expression of disgust or incredulity on the part of the presiding magistrate will be sufficient to neutralize the hypothesis of an advocate, or to shake the testimony of a witness," as the jurors understand that "the Judge advocates the cause of truth alone."

\section{Comment in Criminal Cases}

In criminal cases, although overt judicial comment on evidence became rarer, judges' summing up remained important and became more elaborate. These changes seem to have been closely entwined with the advent and growing powers of defense counsel. John Langbein detected a shift in

\footnotetext{
58. Law Report, supra note 55.

59. Id.

60. Law Report, THE TIMES, June 21, 1799, at 3 (reporting on the case Henderson v. Tempest).

61. Id.

62. Conor Hanly, The Decline of Civil Jury Trial in Nineteenth Century England, 26 J. LEGAL Hist. 253, 255-58 (2005).

63. Hanly, supra note 62 , at 261-62, 265.

64. Id. at 258-59.

65. THE TIMES, Mar. 29, 1850, at D4, quoted in Hanly, supra note 62, at 259.
} 
attitude toward judicial comment in the second half of the eighteenth century, as defense counsel became more prevalent. "[T]he bench became more circumspect about advising juries on the merits." commentaries reflected this change, and some advised judges to refrain altogether from comment on the merits. ${ }^{67}$

Judges, however, seem to have felt a growing need to sum up the evidence for the jury in detail. Again, this development arose in tandem with the increasing role of defense counsel. In the 1730s, defense counsel began to be permitted to examine and cross-examine witnesses, ${ }^{68}$ and cross-examination by defense counsel took on greater importance as the eighteenth century progressed. ${ }^{69}$ The intensity of this cross-examination rendered the judge more passive during trial and trials more complicated. ${ }^{70}$ More complicated cross-examination seems to have spurred judges to want to clarify testimony and issues for the jury at the end of the trial. The practice of detailed judicial summing up was well-established by the early nineteenth century. ${ }^{71}$ Although prosecution counsel, if there was any, described for the jury at the beginning of the trial what evidence he planned to introduce, before 1836 the only legal professional who spoke to the jury after the evidence was heard was the judge.

Detailed judicial summing up would have become even more important because of another power of defense counsel. In a statute of 1836, often referred to as the Prisoners' Counsel Act, defense counsel gained the right to address the jury in felony trials. ${ }^{72}$ The statute had a long legislative history, with extensive debates in Parliament from the early 1820s through the mid-1830s. Three modern scholars have addressed this history at

66. LANGBEIN, ORIGINS, supra note 47, at 322.

67. Id. at 322-23.

68. John H. Langbein, The Criminal Trial Before the Lawyers, 45 U. CHI. L. REV. 263, 311 (1978).

69. LANGBEIN, ORIGINS, supra note 47, at 291-96.

70. Id. at 313-14. David Wolchover has speculated that cross-examination may have encouraged judges to keep more careful notes during trial, to resolve clashes between counsel over what exactly a witness had said previously. These detailed notes would have facilitated judicial summing up of evidence for the jury. David Wolchover, Should Judges Sum Up on the Facts?, 1989 CRIM. L. R. 781, 783.

71. In Parliamentary debates on the role of defense counsel, speakers on either side regularly referred to the judicial practice of summing up. See, e.g., 15 PARL DEB., HC (2d ser.) (1826) 599 (Eng.) (statement of the Attorney General, John Copley) ("The evidence on both sides having been heard, the judge, not as counsel, as was erroneously supposed, for either the prisoner or the Crown, but placed where he was, impartially to administer justice, summed up, and taking a calm, dispassionate, and collected view of the case, and going regularly through the evidence, submitted it to the jury . . .."); id. at 617 (statement of Mr. Tindal) ("[T] he facts were summed up by the judge, who left them to the jury in the most unbiased and unimpassioned manner."); id. at 624 (statement of Mr. Scarlett) ("He agreed with his learned friend, that the administration of justice in this country was pure and unbiased; and he knew no picture more sublime, than that of chief baron Thompson, while engaged in unraveling the evidence, and stating the case to the jury.").

72. Trials for Felony Act, 1836,6 \& 7 Will. 4, c. $114, \S 1$. 
length. ${ }^{73}$ These scholars have tended to stress one argument of opponents of the measure: If defense counsel were permitted to address the jury, counsel for both sides would become more fiercely partisan and the truth would be lost, often to the detriment of the defendant. ${ }^{74}$

Another important argument of opponents of the measure, however, concerned the behavior of judges. A significant objection to this statute was that the rhetoric of defense counsel, with possible misstatements of evidence, would provoke judicial remarks to the jury criticizing the defense and supporting the prosecution. These judicial remarks would often carry great weight with the jury. In the Parliamentary debates in 1826 , several speakers opined that at that time, in the absence of defense counsel addressing the jury, judges were either neutral or favored the defense. ${ }^{75}$ Some speakers claimed that such a judicial attitude would not be likely to survive the rhetoric of defense counsel. John Copley, the Attorney General, argued that the excesses of defense counsel might require the judge to comment disapprovingly, "and, in so doing, he would not be unlikely, in the heat of his address (for judges were but human), to create, however unintentionally, an impression unfavourable to the prisoner in the minds of the jury. ${ }^{, 76}$ Robert Peel, then Home Secretary and a vigorous proponent of criminal law reform, particularly of reducing the number of capital offenses, agreed: "If counsel were allowed to address the jury in favour of the prisoner, the judges would feel and act on the trial differently from their present usual impartiality, and indulgence to the prisoner." 77

The problem of judges appearing to favor the prosecution in an effort to counteract defense rhetoric concerned members of the bench and led many of them to oppose the measure. ${ }^{78}$ In 1834, Mr. Justice Park, an opponent of the measure, explained this difficulty:

73. David J.A. Cairns, Advocacy and the Making of the Adversarial Criminal Trial 1800-1865, 67-97 (1998); ALlysOn N. MAY, THE BAR AND THE OLD BAILEY, 1750-1850, 176-201 (2003); John M. Beattie, Scales of Justice: Defense Counsel and the English Criminal Trial in the Eighteenth and Nineteenth Centuries, 9 LAW. \& HIST. REv. 221, 250-58 (1991).

74. CAIRNS, supra note 73, at 69; MAY, supra note 73, at 178; Beattie, supra note 73, at 252-54. See also 15 PARL DEB., HC (2d. Ser.) (1826) 599 (Eng.) (statement of John Copley) (fearing that counsel would "convert the court into an arena ... where, instead of endeavoring to elicit the truth by a reference to plain facts, or the real merits of the case, the time of the public would be wasted by contests between the counsel on either side, animated, as they would be, by all the excitement, zeal, and pertinacity, which such contests usually inspired").

75. 15 PARL DeB., HC (2d ser.) (1826) 601 (Eng.) (statement of the Attorney General, John Copley); id. at 606-07 (statement of Robert Peel); id. at 617 (statement of Mr. Tindal). See also CAIRNS, supra note 73 , at 112-13.

76. Id. at 601 (statement of John Copley). David Cairns has discussed this argument by Copley. CAIRNS, supra note 73, at 69.

77. 15 PARL DEB., HC (2d ser.) (1826) 606 (Eng.) (statement of Robert Peel).

78. CAIRNS, supra note 73, at 113-17. 
If you have speeches for prisoners, you change immediately the nature of things; it is the duty of the judge to watch for the prisoner's benefit, and take every objection for their benefit; instead of that, there will be some young gentleman making speeches, and talking of things quite extraneous, and that will turn the judge immediately into the prosecutor's counsel, to prevent false topics being made use of to the defeat of justice. ${ }^{79}$

The Act complicated the judicial task of summing up the evidence. In implementing the Act in 1837, the common law judges determined that prosecution counsel could reply following arguments by defense counsel, even if no evidence was introduced for the defendant. ${ }^{80}$ Judges therefore had to take into account in their summing up two speeches by opposing counsel after presentation of evidence.

The concern about judicial remarks seeming to favor the prosecution proved prescient. Some English judges developed the reputation of summing up strongly in favor of the prosecution. In the most recent Bench Book, published in 2010, the Judicial Studies Board believed it necessary to warn judges against a one-sided summing up for the prosecution. ${ }^{81}$

The practice of summing up became more directive over time, as judges moved from simply reading their trial notes in the early- and midnineteenth century to marshalling the evidence in the late nineteenth century. The earlier practice was simply to read trial notes to the jury with minimal direction. ${ }^{82}$ In 1848 , the author of a treatise criticized the "too common mode of summing up" by "many able, but somewhat lazy judges": "Gentlemen, if you think so and so, you will find for the plaintiff, if you think otherwise, you will find for the defendant; gentlemen, the

79. Select Committee on the Receipt and EXPENDiture of County Rates, RePort, 1834, H.C. 14-I, at 143 (U.K.), quoted in CAIRNS, supra note 73, at 114-15.

80. MAY, supra note 73, at 199.

81. Judicial Studies Board, Crown Court Bench Book: Directing the Jury 6 (2010) (declaring, in a section entitled "Balance": "A one-sided summing up is not likely to be a fair summing up. The judge is not required to ignore the fact, if it is the fact, that the defendant's case appears to be at odds with the prevailing evidence, but it is not his job to support or to appear to support the prosecution at the expense of fair and independent consideration of the evidence by the jury.").

82. Charles Dickens described this satirically as "the old-established and most approved form." CHARLES DiCKENS, PICKWICK PAPERS, ch. 34 (1837). In the fictional case Bardell v. Pickwick, the trial judge "read as much of his notes to the jury as he could decipher on so short a notice, and made running comments on the evidence as he went along. If Mrs. Bardell were right, it was perfectly clear that Mr. Pickwick was wrong, and if they thought the evidence of Mrs. Cluppins worthy of credence they would believe it, and if they didn't, why, they wouldn't. If they were satisfied that a breach of promise of marriage had been committed, they would find for the plaintiff with such damages as they thought proper; and if, on the other hand, it appeared to them that no promise of marriage had ever been given, they would find for the defendant with no damages at all." Id. Lord Devlin commented that Charles Dickens's son, Sir Henry Dickens, stuck close to this model when he was on the bench. PATRICK DEVLIN, TRIAL BY JURY 118 (3d ed. 1966). 
question is for you." "\$3 The author worried that, in complicated cases, this method of summing up "is almost tantamount, if not to a direct denial of justice, at least to a decision of the issue by lot." ${ }^{~} 4$ To prevent juror confusion, writers recommended marshalling the evidence instead: describing the evidence to the jury not in the order in which it was given at trial, but as it pertained to each issue to be proved.$^{85}$ Lord Alverstone, who was called to the bar in 1868 and elevated to the bench in 1900, explained that, before he went on the bench, the old practice of judges reading from their notes without arrangement began to give way to the practice of marshalling the evidence, and as a judge he followed the "new practice." 86 Simply reading from trial notes, however, remained a tempting option for judges, as it involved less work than marshalling the evidence. ${ }^{87}$

Authors observed that the summing up-aside from any obvious comment on evidence - could be highly influential with the jury. "Quite apart from any expression of opinion by the judge, the way in which he marshals the facts and gets rid of irrelevancies may present a strongly persuasive argument for one side or the other - and it must be remembered that it is the judge who has the real 'last word' with the jury." 88 Trial judges had widely varying styles of summing up and comment. Although

83. John P. TAYlor, A Treatise on the LaW of Evidence, As Administered in England AND IRELAND 28 (A. Maxwell \& Son 1848).

84. TAYLOR, supra note 83. The writer recommended that a judge temperately state to the jury his opinion of the merits of the case, and the reasons for his opinion. The judge was no more liable to be prejudiced or partial than the jury, and his "long experience in courts of justice must, of necessity, have rendered him far more competent than they can be, to unravel the tangled threads of conflicting testimony." Id.

85. Writers called this "predigesting" or "dissecting" the evidence. See GLANVILLE WILLIAMS, The Proof of GuILt: A StUdy OF THE English Criminal Trial 303 (3d ed. 1963) ("predigest"); DEVLIN, supra note 82 ("[A] jury probably finds some dissection of the evidence more helpfulsomething which extracts the issue to be proved and segregates the material relating to each.").

86. LORD AlVERSTONE [RICHARD WEBSTER], RECOLlECTIONS OF BAR AND BENCH 289 (1915).

87. See DEVLIN, supra note 82; Wolchover, supra note 70, at 784. In 1981, Lord Hailsham found it necessary to recommend "a correct but concise summary of the evidence and arguments on both sides" and observed that a "direction is seldom improved and may be considerably damaged by copious recitations from the total content of a judge's note book." R v. Lawrence, [1982] A.C. 510,519 (H.L.) (appeal taken from Eng.).

88. WILLIAMS, supra note 85, at 304; see also DEVLIN, supra note 82, at 117 ("[I]t is obvious that they [the jury] are likely to be very much influenced by his [the judge's] opinions on the facts and the way in which he presents them ...."); $i d$. at 119 (discussing proposals that judges should be forbidden to comment on the evidence: "I doubt if this would achieve what the proposers want unless the judge was prohibited altogether from dealing with the evidence, for the mode of its presentation to the jury is likely to influence them just as much as any express comment."); 1 JAMES FITZJAMES STEPHEN, A HISTORY OF THE CRIMINAL LAW OF ENGLAND 455 (1883) ("The mere effort to see what is essential to a story, in what order the important events happened, and in what relation they stand to each other must of necessity point to a conclusion. The act of stating for the jury the questions which they have to answer and of stating the evidence bearing on those questions and showing in what respects it is important generally goes a considerable way towards suggesting an answer to them, and if a judge does not do as much as this he does almost nothing."). 
"misdirection of fact" was a ground of appeal, its definition was vague. ${ }^{89}$ The way in which the judge presented the defense was a special target on appeal. Even in presenting the defense, however, the trial judge was allowed a great deal of discretion. ${ }^{90}$

As the practice of comment on evidence became rarer, the summing up became more salient. In the 1960s, Lord Devlin declared: "The summingup is a vital part of the jury trial.",91

\section{Establishment of Trial Courts and Courts of Appeal with Separate Personnel}

Although England established an appellate court with separate personnel from the trial courts in the Judicature Acts of $1873-1875,{ }^{92}$ the prestige and powers of the trial bench were not greatly affected.

In consolidating the old courts into one Supreme Court of Judicature, ${ }^{93}$ the 1873 Act divided the English judiciary into two permanent divisions: one called the High Court of Justice with mostly original jurisdiction, the other the Court of Appeal. ${ }^{94}$ The House of Lords remained the court of final appeal, but its judicial functions were transferred to a judicial committee. ${ }^{95}$ In a break with previous practice, Parliament determined that the ordinary judges of the Court of Appeal should be separate from the ordinary trial judges. ${ }^{96}$

There were two main reasons for having separate personnel in the Court of Appeal. ${ }^{97}$ First, and most important, was the goal of speeding up

89. Lord Devlin defined it as "anything which causes an appellate tribunal to think that the presentation of the facts was seriously unbalanced." DEVLIN, supra note 82, at 117.

90. In a famous murder case in 1952, the judge's summation of the prosecution's case took up four or five pages in the transcript of the short hand note, but he devoted only one sentence to the defense, that the defendant denied the facts alleged against him. WILLIAMS, supra note 85, at 304 (describing the trial of Craig and Bentley). The Court of Appeal affirmed. Id.; see also id. at 304-05 n.69 (observing that the Court of Appeal had not been consistent in its treatment of the trial judge's summing up of the defense).

91. DEVLIN, supra note 82, at 116.

92. Supreme Court of Judicature Act, 1873, 36 \& 37 Vict. c. 66; Supreme Court of Judicature Act, $1875,38 \& 39$ Vict. c. 77.

93. $36 \& 37$ Vict. c. $66, \S 3$ (1873).

94. Id. $\S 4$.

95. A statute of 2005 replaced the appeal committee of the House of Lords with a Supreme Court. Constitutional Reform Act, 2005, 53 Eliz. 2, c. 4. The Supreme Court began operation in 2009.

96. The Court of Appeal consisted of various ex officio members and five ordinary members. Of the ex officio members, only the Master of the Rolls usually sat. R.J. WALKER \& M.G. WALKER, THE ENGLISH LEGAL SYSTEM 91 (1967). The court usually sits in divisions of three judges.

97. I have not found discussion of any reasons in the existing secondary literature. 
the administration of justice. ${ }^{98}$ English courts in the nineteenth century were under increasing pressure because of "a new class of business": complicated litigation concerning railways and other joint stock companies. ${ }^{99}$ In the years leading up to the Judicature Acts, there were many complaints about the sluggishness and confusion of the system of post-verdict review and appeals. ${ }^{100}$ The First Report of the English Judicature Commission of 1869 and speakers in the Parliamentary debates in the 1870s emphasized the importance of an appellate court that sat continuously and so was able to decide cases faster. ${ }^{101}$ If trial judges were also to sit as appellate judges, as they did before the Acts, appellate court sittings would be interrupted while judges presided over trials. A separate, dedicated personnel was needed to handle appeals quickly.

A second reason for separate personnel was doubt about whether an appeal could be efficacious if judges of the appellate court were the same as judges of the first instance. The principle was becoming established in English law that a judge should not hear an appeal if he had decided the case below. A different judge would be less attached to the result below and more likely to correct error. As discussed previously, by the midnineteenth century the court of Exchequer Chamber had adopted this principle. ${ }^{102}$ The principle appeared in the Act of 1875 , prohibiting a judge of the Court of Appeal from hearing an appeal from any judgment or order which he had made or was made by any division of the High Court of which he was currently a member. ${ }^{103}$ This concern to prevent judges from hearing appeals in cases they had decided below made it more desirable to separate trial from appellate personnel in order to maintain a speedy, efficient system. Having to constitute an appellate court by excluding

98. The members of the English Judicature Commission viewed it as their charge to make recommendations "to provide for the more speedy, economical and satisfactory dispatch of the judicial business." First Report of the English Judicature Commission, supra note 43, at 254-55.

99. Id. at 258-59.

100. See id. at 281-88; see also 214 PARL DEB., HL (3d ser.) (1873) 349-56 (statement of the Lord Chancellor [Roundell Palmer, Lord Selborne] introducing the bill that became the Judicature Act of 1873); 216 PARL DEB., HC (3d ser.) (1873) 640-55 (statement of Mr. Charley); id. at 664 (statement of Mr. Osborne Morgan); id. at 673-75 (statement of Mr. James); id. at 681-83 (statement of the Solicitor General, William Vernon Harcourt); 216 PARL DEB., HC (3d ser.) (1873) 861 (statement of Mr. Amphlett); 217 PARL DEB., HL (3d ser.) (1873) 886-87 (July 24, 1873) (statement of Lord Hatherly).

101. See First Report of the Judicature Commission, supra note 44, at 283 (arguing that the existing system, in which judges had too little time to hear appeals because of the pressing demands of presiding over trials and other responsibilities, was a "very serious" inconvenience); see also 216 PARL DEB., HC (3d ser.) (1873) 655 (statements of Mr. Charley and Mr. Amphlett); id. at 881 (statement of Mr. Williams) ("Now, the success of the new scheme was absolutely dependent upon having a speedy and economical appeal to a tribunal constantly at hand and continuously sitting.").

102. See supra text accompanying note 45 .

103. Supreme Court of Judicature Act, 1875,38 \& 39 Vict. c. 77, § 4. The latter situation could arise if the ex officio members of the Court of Appeal heard appeals, which normally they did not, except for the Master of the Rolls. 
particular members for certain cases was an administrative nuisance and delayed appeals. ${ }^{104}$ In addition, the practice of trial judges reviewing each other's decisions could lead to retaliation for reversals or cooperation in upholding decisions that would hinder proper correction of error. ${ }^{105}$

Despite the creation of an appellate court with largely separate personnel from the trial court, there was no great difference of prestige between ordinary appellate and trial judges and no difference at all in salary. The salary of the ordinary judges of the Court of Appeal (styled Lords Justices of Appeal) was $£ 5,000$ apiece, exactly the same as the salaries of the ordinary judges of the trial courts (styled Judges of the High Court). ${ }^{106}$ Parliament had set the salary of $£ 5,000$ for the ordinary (puisne) common law judges in $1832,{ }^{107}$ and the Judicature Acts simply continued it for both trial and appellate judges. This remained the salary for the two sets of judges until 1954, when Parliament raised them equally to $£ 8,000 .^{108}$ Both types of judges continue to enjoy similar - and considerabledignitary distinctions. An appointment as a judge of the High Court brings with it a knighthood. ${ }^{109}$ Both sets of judges are referred to by the same title on the bench: "My Lord" or "My Lady."110

Gradually, appellate judges came to be more differentiated from trial judges, but the differences have not been great. For many years, a sort of fiction was maintained that there was hardly any distinction between

104. The First Report of the Judicature Commission complained of this problem in the court of Exchequer Chamber. First Report of the Judicature Commission, supra note 44, at 283.

105. See id. (expressing concern that trial judges who also sat as appellate judges might engage in retaliatory behavior: "[A]s the Judges of Appeal are not appointed or selected specially to act as such Judges, and the Judges who have been overruled to-day may to-morrow themselves sit in appeal from some decision of the Judges who have taken part in overruling them, [the situation] is eminently unsatisfactory.").

106. Supreme Court of Judicature Act, 1873, 36 \& 37 Vict. c. 66, § 13. In 1873, one MP expressed concern that, after paying necessary expenses for staff and traveling circuit, the judges of the High Court would receive only $£ 4,500$. In his view, "it was not likely that the services of the best men of the Bar could be obtained for that low sum." 216 PARL DEB., HC (3d ser.) (1873) 1561 (statement of Mr. Henley). Lord Carnarvon agreed. "It must not be forgotten that parsimony in the matter of salaries paid to Judges meant a lowering of the whole judicial standard; because it was not to be expected that men of the highest character and legal ability would accept laborious duties with a niggardly scale of payment attached thereto.” 217 PARL DEB., HL (3d ser.) (1873) 883 (statement of Lord Carvarvon).

107. 2 \& 3 Will. 4 , c. $116(1832)$.

108. Judges' Remuneration Act, 1954, 2 \& 3 Eliz. 2, c. 27 (raising the judges' salaries to $£ 8,000$ ). The Judges' Remuneration Act, 1965, c. 61 further raised the judges' salaries to $£ 10,000$. The 1965 Act allowed the pay of superior judges to be raised in the future by Order in Council, subject to the approval of both Houses of Parliament. Id. The Administration of Justice Act of 1973 repealed the Judges' Remuneration Act and declared that judges' salaries would be set by the Minister of Civil Service or by the Lord Chancellor. Administration of Justice Act, 1973, c. 15, § 9.

109. By convention, there is a minor distinction in dignity between the Lords Justices of Appeal and the Justices of the High Court: The former are made members of the Privy Council, while the latter are not. The Lords Justices of Appeal are therefore entitled to the honorific "The Right Honorable."

110. Penny Darbyshire, SitTing In Judgment: The Working LiVes Of Judges (2011). 
appellate and trial judges. In 1933, a leading legal commentator asserted that High Court judges, already enjoying great prestige, did not look for promotion to the Court of Appeal, and the lack of difference in salary seemed to support that view. ${ }^{111}$ However, the difference between the top salaries at the bar and the static judicial salary of $£ 5,000$, first established in 1832 , continued to increase. In 1959, a prominent judge proclaimed in the House of Lords that the possibility of promotion from the High Court to the Court of Appeals was an inducement - and a necessary one - to service as a judge. ${ }^{112}$ A government report presented to Parliament in 1974 argued that, although the salaries of Lords Justices of Appeal and High Court Judges had always been the same, a difference was justified. ${ }^{113}$ "[E]xceptional intellectual qualities are called for in a Lord Justice of Appeal, and appointment to the Court of Appeal from the High Court Bench is regarded as a promotion." "In recognition of the promotion, the report recommended a higher salary for appellate judges. The report, however, cautioned that the difference should not be large because of the inconvenience of the High Court judges' circuit work. ${ }^{115}$ For 2015, the salary of the Lord Justices of Appeal is $£ 202,668$, and the salary of the judges of the High Court is $£ 177,988 .{ }^{116}$

Judges of the trial court have been appointed from barristers of considerable experience and high professional reputation, ${ }^{117}$ although this

111. "It is a fair thing to say that when a man is appointed to the Supreme Court [the High Court] he does not look for promotion, but takes his job - with its high social status, its knighthood, its $£ 5,000$ a year, and its rather large quantum of leisure - as something final: an apex, not a ladder." R.C.K. ENSOR, COURTS \& JUdGES IN FRANCE, GERMANY, AND ENGLAND 5 (1933).

112. 220 PARL DEB., HL (5th ser.) (1959) 406 (statement of Lord Silkin) ("[I]n many cases, members of the Bar make a great sacrifice in becoming High Court Judges, and one of the inducements - and I think we ought to hold out inducements to them - is the opportunity which may arise of their becoming members of the Court of Appeal and Members of your Lordships' House. . . . We have all known cases of barristers whose earnings have been $£ 30,000$ or $£ 40,000$ a year who have made the sacrifice and become Judges at $£ 5,000$ a year, as the salary now is.").

113. REVIEW BODY ON TOP SAlARIES, RePORT NO. 6: REPORT ON TOP SALARIES, 1974-75, Cmnd. 5846, at 93 (U.K.).

114. Id. at 93; see also SHIMON SHETREET, JUdGES ON TRIAL: A STUDY OF THE APPOINTMENT AND ACCOUNTABILITY OF THE ENGLISH JUDICIARY 80 (1976).

115. SHETREET, supra note 114 , at 80.

116. See Ministry of Justice, Ministry of Justice Judicial Salaries from 1 April 2015, https://www.gov.uk/government/uploads/system/uploads/attachment_data/file/419123/judicial-salaries1-april-2015.pdf (last visited May 13, 2016).

117. The Act of 1873 required that appointees to the High Court be barristers of not less than ten years' standing. Supreme Court of Judicature Act 1873, 36 \& 37 Vict. c. 66, § 8. In 1959, Lord Goddard, former Chief Justice of England, told the U.S. National Conference on Judicial Selection and Court Administration that it would be "most unusual" for anyone of fewer than 20 to 25 years standing at the bar to be appointed a High Court judge. Lord Goddard [Rayner Goddard], Politics and the British Bench, 43 J. AM. Jud. Soc'y 124, 125 (1959). Furthermore, such judges were usually chosen from among Queen's Counsel, the senior rank at the bar whose members were "practically entirely engaged in the conduct of cases in court ...." Id. 
tradition may be changing. Since 2006, a fifteen-member Judicial Appointments Commission recommends candidates for appointment as High Court and Court of Appeal judges. ${ }^{118}$ Tenure for judges of the High Court and Court of Appeal is, as it has been for common law judges since $1761,{ }^{119}$ for life during good behavior. ${ }^{120}$

A practice grew up, and endures to this day, of appointing members of the appellate court solely from judges of the trial court, ${ }^{121}$ and usually those of considerable experience. Members of the bar therefore cannot leap over the trial court directly to the appellate court and establish an immediate superiority. Commentators have observed that this practice has costs; some prominent members of the bar would leave practice to become appellate judges, but refuse to leave it to become trial judges. ${ }^{122}$ Nevertheless, the advantages of the system of promotion are thought to outweigh the costs. Trial judges are well respected, and appellate judges are deeply familiar with presiding over trials and can fashion rules accordingly.

Despite the separation of trial judges from appellate judges, the English judiciary has continued its tradition of having a respected trial bench comparable in quality to the appellate bench.

118. The Judicial Appointments Commission was created by the Constitutional Reform Act 2005, c. $4, \S 61$. The act specifies that "[s]election must be solely on merit," and that "[a] person must not be selected unless the selecting body is satisfied that he is of good character." Id. $\S 63$. The Commission "must have regard to the need to encourage diversity in the range of persons available for selection for appointments." Id. § 64. The Commission describes its application and selection process at JUDICIAL APPOINTMENTS COMMISSION, Application and Selection, https://jac.judiciary.gov.uk/application-andselection (last visited May 13, 2016). In 2015, the Judicial Appointments Commission announced a pilot program to train "women, those from a black, Asian or minority ethnic background and those "from less advantaged social or educational backgrounds" to prepare for selection as deputy high court judges. Owen Bowcott, High Court to Go on Recruitment Drive for "Non-traditional" Judges, THE GUARDIAN, Apr. 8, 2015, http://www.theguardian.com/law/2015/apr/08/high-court-recruitment-drivernon-traditional-judges. Deputy high court judges are expected to apply to become full-time high court judges. Id. Lady Justice Hallett, who announced the program, stated that candidates for deputy high court judge may have "little or no experience of attending or appearing in the high court—or any court for that matter." Id.

119. Commissions and Salaries of Judges Act, 1760, 1 Geo. 3, c. 23.

120. Supreme Court of Judicature Act, 1873, 36 \& 37 Vict., c. 66, § 9 ("life"); Supreme Court of Judicature Act, 1875, 38 \& 39 Vict., c. 77, § 5 ("good behaviour"). Judges of the Court of Appeal and the High Court may be removed only with the approval of both Houses of Parliament. Id.

121. See COURTS AND TRIBUNALS JUdiciary, Court of Appeal Judges, https://www.judiciary.gov.uk/about-the-judiciary/who-are-the-judiciary/judicial-roles/judges/coajudges/ (last visited May 13, 2016) ("[T] the High Court Judges."); Home AfFairs COMmitTeE, ThiRd RePORT Judicial APPOINTMENTS PROCEDURES, 1995-6, H.C. 52 ("Lords Justices of Appeal, who sit in the Appeal Courts, are invariably appointed on promotion from the ranks of High Court Judges."). Since 1946, the judges of the Court of Appeal have been appointed exclusively from serving judges of the High Court, and there were few exceptions before then. Gavin Drewry, Louis Blom-Cooper \& Charles Blake, The Court of APPEAL 111 (2007).

122. DREWRY ET AL., supra note 121. 


\section{E. The Special Situation of Criminal Appeals and Comment on Evidence}

The common law systems were especially slow to develop appeals in criminal cases. ${ }^{123}$ In England, the procedure of ordering a new trial, so freely used to correct jury and other error in civil cases, was not available in criminal cases. There was no way to correct an improper verdict of acquittal, if a jury insisted on it, because of the double jeopardy rule. ${ }^{124}$ If an improper conviction occurred, the trial judge could request executive clemency, and judicial requests were rarely denied. ${ }^{125}$ Until the twentieth century, the only way to correct an erroneous conviction within the court system was by reservation of the trial judge, and then only for errors of law. The trial judge reserved a point to be decided by all the judges together, an informal process that at first did not result in a formal judgment. ${ }^{126}$ The process became more regular, and in 1848 was formalized in a statute creating the Court for Crown Cases Reserved. ${ }^{127}$ Still, that court could only be invoked on reservation by the trial judge of a point of law, and was little-used. ${ }^{128}$

Judges strongly resisted routine appeals in criminal cases. The judges' reasons included concerns that there were not enough judges to staff a court of criminal appeals, and that a right of appeal by the defense should be matched by a corresponding right of the prosecution. ${ }^{129}$ The judges' deepest worry, and that of other opponents of criminal appeals, was that appeals in criminal cases would cause delay and detract from the swiftness of punishment necessary to deterrence. Deterrence through swift and severe punishment was all the more important because England long lacked an effective police force. ${ }^{130}$ As Lord Hatherley, Lord Chancellor, put it in a debate in the House of Lords in 1870:

All who have gone into the subject of punishment are agreed that to be effectual it should be speedy as well as certain, and nothing produces a greater effect on a criminal's mind than to

\footnotetext{
123. See LANGBEIN, LERNER \& SMITH, supra note 1, at 702-05.

124. Id. at 443-44.

125. Id. at 626-28.

126. James Oldham, Informal Lawmaking in England by the Twelve Judges in the Late Eighteenth and Early Nineteenth Centuries, 29 LAW \& Hist. REV. 181, 191-99 (2011); Randall McGowen, Forgery and the Twelve Judges in Eighteenth-Century England, 29 LAW \& HIST. REV. 221, 255-56 (2011).

127. Phil Handler, The Court for Crown Cases Reserved, 1848-1908, 29 LAW \& HIST. REV. 259,

261-64 (2011); Benjamin L. Berger, Criminal Appeals as Jury Control: An Anglo-Canadian Perspective on the Rise of Criminal Appeals, 10 CAN. CRIM. L. REV. 1, 11-12 (2005).

128. Berger, supra note 127 , at 12.

129. RosEmARY PATTENDEN, ENGLiSh CRIMINAL APPEALS 1844-1994, at 23 (1996).

130. Id.
} 
find that, as sometimes happens, only a few days intervene between the commission of the crime and the trial, and only about a week between the latter and the execution. The terror caused by this speedy determination is one of the most effective means of impressing the criminal class. Now, this would be fatally interfered with if those desirous of interfering with a sentence had to apply to a tribunal for the purpose of re-hearing the case. ${ }^{131}$

After two notable miscarriages of justice in the late nineteenth and early twentieth centuries, public opinion strengthened in favor of a regular system of appeal to correct error. ${ }^{132}$ In 1907, Parliament created the Court of Criminal Appeal. ${ }^{133}$

The Court of Criminal Appeal was highly unusual for the time because it was staffed with High Court judges from the King's Bench division. ${ }^{134}$ In other words, the appellate court was staffed with the very judges who ordinarily heard criminal cases in the first instance. This was the model that Parliament had rejected for civil appeals in the Judicature Acts, as discussed above. It appears that judges, although they lost the fight to prevent a criminal court of appeal, won an appellate bench that likely would be more deferential to trial judges. Not until 1966 was the Court of Criminal Appeal made part of the Court of Appeal, and mainly staffed with a separate personnel of appellate judges, but even then, trial judges could and did regularly sit on the Court of Criminal Appeal. ${ }^{135}$

Through the 1960s, trial judges were permitted wide latitude in making comments on evidence to the jury. Beginning in the 1990s, the Court of Criminal Appeal issued a series of decisions somewhat limiting the trial court's discretion in commenting, although the power remains. ${ }^{136}$

Currently in England, judicial summing up is expected and may be a ground for reversal if omitted, ${ }^{137}$ particularly in a complicated case. ${ }^{138}$ The judge must describe the defense, ${ }^{139}$ but may point out inconsistencies in the defense case. ${ }^{140}$ The most recent edition of the Bench Book from the

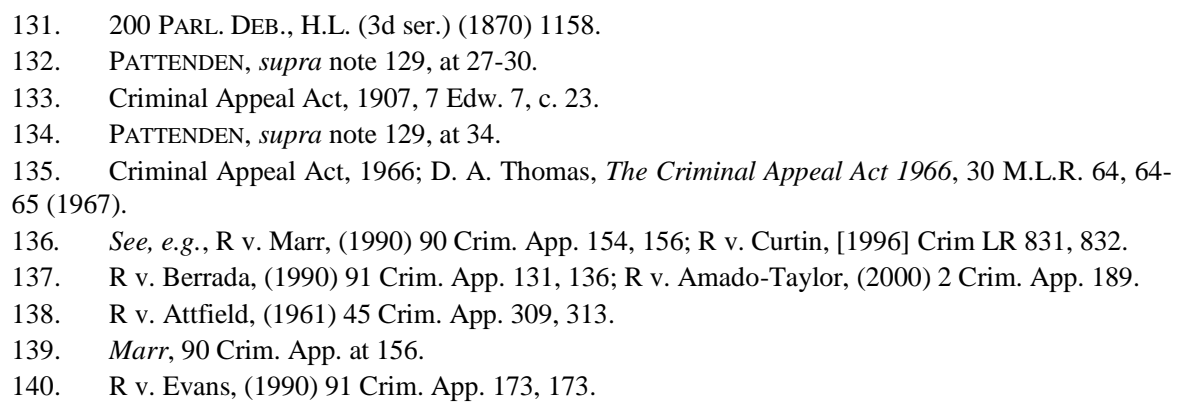


Judicial Studies Board leaves large discretion to the trial judge, but cautions against simply summarizing the testimony in the order it was given at trial. ${ }^{141}$ English judges now appear regularly to use flow charts of necessary jury decisions - called decision trails or "routes-to-verdict"-to assist the jury in reaching a verdict. ${ }^{142}$

English trial judges retain the power to comment overtly on the evidence, but exercise it less frequently than before. ${ }^{143} \mathrm{~A}$ case often cited in modern sources for the judicial power to comment dates from 1917, in which the trial judge described the defendant's story as "a remarkable one." ${ }^{144}$ Commentators in the 1960s asserted a strong judicial power to comment on evidence, though they suggested that it was not always used. ${ }^{145}$ In 1996, an appellate judge declared: "We do not doubt that the degree of adverse comment allowed today is substantially less than it was 50 years ago." 146 As justification for the power to comment, judges and commentators emphasized, and continue to emphasize, the greater experience of the judge relative to lay jurors, and the tendency of jurors to be confused by the arguments of counsel. ${ }^{147}$

\footnotetext{
141. JUDICIAL STUDIES BOARD, supra note 81, at 4 ("How to organise a summary of the evidence is a matter for individual judgement based upon the nature of the evidence and the issues in the case. Almost never will it be helpful or appropriate simply to summarise each witness in turn.”). The manual further states: "Brevity is a virtue, provided that essential matters are not thereby omitted. Essential matters are those which bear directly on the issues the jury has to determine. The judge is not obliged to repeat every byway taken by the evidence, but is entitled to assess what is important and what is peripheral." Id. at 5 . The Bench Book describes five different ways that evidence may be organized in the summing up. $I d$.

142. Paul Marcus, Judges Talking to Jurors in Criminal Cases: Why U.S. Judges Do It So Differently from Just About Everyone Else, 30 ARIZ. J. INT'L \& COMP. L. 1, 54-55 \& n.123 (2013).

143. See Marcus, supra note 142, at 24 n.72.

144. R v. O’Donnell, (1917) 12 Crim. App. 219, 221.

145. WiLliams, supra note 85, at 303-04 \& n.67; DEVLIN, supra note 82, at 118 ("Some judges ... will indicate an opinion on some of the issues or on the value of some pieces of evidence: unless it be in favour of the defence in a criminal trial it would be exceptional for the judge to put forward an opinion on the case as a whole. Nevertheless a judge is permitted to express his opinion freely and, if he wishes, strongly. The only limitation placed on him is that he must not put any point unfairly and must make it clear to the jury, either expressly or by implication, that on the issues of fact which are left to them they are free to give his opinion what weight they choose."); WILLIAM R. CORNISH, THE JURY 123 (1968) ("The judge is free to comment as he likes on the strength of the case made out by either side .... The judge's discretion in commenting upon the evidence is limited only in a minor degree.").

146. R v. Wood, (1996) 1 Crim. App. 207 (Staughton L.J.).

147. R v. Cohen, (1990) 2 Crim. App. 197, 208; TAYLOR, supra note 83, at 28; Wolchover, supra note 70 , at 788 . One commentator, however, has argued that juries are sufficiently sophisticated, and counsel sufficiently clear and business-like, that judicial comment and summing up are unnecessary and potentially dangerous. Wolchover, supra note 70, at 788-92.
} 


\section{FEDERAL COURTS IN THE UNITED STATES}

\section{A. The Federal Courts to the Late Nineteenth Century}

\section{Organization}

In 1789, the first Congress chose a structure for the federal courts largely resembling that of the English circuit system. The highest judges in the land, the justices of the Supreme Court, were to ride circuit and to sit regularly as trial judges.

In the Judiciary Act of $1789,{ }^{148}$ Congress created two types of federal trial courts: the district courts and the circuit courts. A separate federal district court was created for each state which had ratified the Constitution, and one district judge was authorized for each. ${ }^{149}$ Except for its grant of admiralty jurisdiction, the district court was conceived as "a very inferior court indeed." 150 The federal circuit courts, in contrast, were to have broader jurisdiction, including some appeals from the district court. Congress grouped the districts into three circuits: the Eastern, the Middle, and the Southern. ${ }^{151}$ Circuit courts were to sit twice a year in each district of the circuit. Each sitting of the circuit courts was to consist of two justices of the Supreme Court and the local district judge. ${ }^{152}$ The federal Supreme Court consisted of the Chief Justice and five associate justices. ${ }^{153}$ Given the composition of the circuit courts, the vast extent of the circuits, and the poor conditions of travel in the eighteenth century, the justices of the Supreme Court necessarily spent much of their time on circuit. ${ }^{154}$

These arrangements were the result of extensive political compromise. ${ }^{155}$ Many of the political battles and positions that formed around the Federal Judiciary Act of 1789 endured into the twentieth century. The Federalists wanted a strong federal judiciary, including lower courts, not beholden to the states but supporting national power and uniform legal rules throughout the country. Such a system, they believed, was conducive to commercial development; state courts and state

148. 1 Stat. 73 .

149. Id. $\S 2$.

150. 1 Julius Goebel, JR., History of the SuPREMe Court of THE United StATES 473 (1971).

151. Judiciary Act of $1789 \S 4$.

152. Id.

153. Id. $\S 1$.

154. GOEBEL, supra note 150, at 553-54.

155. For discussion of these battles and compromises, see 4 THE DOCUMENTARY HiSTORY OF THE SuPREME Court OF THE United StATES, 1789-1800, at 5, 10-17 (Maeva Marcus et al. eds., 1992); Anthony J. Bellia \& Bradford R. Clark, The Original Source of the Cause of Action in Federal Courts: The Example of the Alien Tort Statute, 101 VA. L. REV. 609, 638-39 (2015). 
legislatures (who at that time selected judges in most states) had proven eager to support debtors at the expense of creditors. ${ }^{156}$ The Anti-Federalists thought lower federal courts unnecessary and wanted to limit their jurisdiction and to tie them to the states, and local interests and rules, as much as possible.

The Federalists succeeded in establishing federal trial courts, over the objections of the Anti-Federalists, but they paid a price. Federal question jurisdiction was largely left to the state courts. Federal district judges were tied to the states; they were required to be residents of their districts, coterminous with states. ${ }^{157}$ The Judiciary Act of $1789,{ }^{158}$ and more specifically the Process Acts of $1789^{159}$ and $1792,{ }^{160}$ required the federal courts to follow the "forms of writs and executions" and the "forms and modes of proceeding" of the state in which each court sat, if there was no federal statute on the subject. ${ }^{161}$ The required conformity was "static," because it required conformity to state forms of proceeding as they existed in 1792. ${ }^{162}$ Because Supreme Court justices, when they held circuit courts, could not be expected to know the details of state practice, the district judge was there to help them. ${ }^{163}$

Supreme Court justices were kept busy running around the country on circuit. Members of both parties saw advantages in this system. There were many reasons for Congress's attraction to the circuit system. ${ }^{164}$ First was the desire to save money by making members of the federal bench do double duty as trial and appellate judges. As in England, the effect was to slow down the administration of justice. ${ }^{165}$ Second, travelling around the country hearing trials would expose federal justices to state laws and practice, and keep them directly in contact with juries. Third, being visited regularly by the highest judges of the federal bench would hopefully

156. Henry Friendly, The Historic Basis of Diversity Jurisdiction, 41 HARV. L. REV. 483, 497-99 (1928); John Frank, Historical Bases of the Federal Judicial System, 13 LAW \& CONTEMP. PROBS. 3, 25 (1948).

157. Judiciary Act of $1789 \S 3$.

158. Id. $\S \S 14,34$.

159. Act of Sept. 29, 1789, c. 21, § 2, 1 Stat. 93 (repealed 1792).

160. Act of May 8, 1792, c. 36, § 2, 1 Stat. 275 (repealed 1872).

161. Id. The Process Acts have not been much noticed by historians of the federal courts, until recently. For an extensive discussion of the relevant provisions of the Judiciary Act and the Process Acts, see Bellia \& Clark, supra note 155, at 627-55. See also 4 DocumENTARY HIsTORY, supra note 155 , at 112-13; GOEBEL, supra note 150 , at 509-10.

162. See Bellia \& Clark, supra note 155, at 655.

163. Id.

164. See Joshua Glick, On the Road: The Supreme Court and the History of Circuit Riding, 24 CARDOZO L. REV. 1753, 1757-61 (2003).

165. RuSSELl R. WHEELER \& CYNTHIA HARRISON, CREATING THE FEDERAL Judicial SySTEM 7-8 (3d ed. 2005). 
impress citizens favorably toward the national government. ${ }^{166}$ Fourth, if trials were conducted by such a prestigious bench, the judgments of the federal courts would likely be more respected and authoritative. This was especially important in criminal cases, in which there was no appeal. Fifth, there was the advantage that Matthew Hale described for the English circuit system: maintaining uniformity of legal rules throughout the country.

For justices, the hardships of riding circuit far outweighed these advantages. The justices complained bitterly about the duty from the beginning. The federal circuits required travel over vast distances: 1,900 miles for the Southern Circuit, the longest. ${ }^{167}$ Justices had to cope with overturned coaches, runaway horses and vehicle crashes, near drownings in flooding rivers, frozen river crossings, ${ }^{168}$ and "rascally" inns. ${ }^{169}$ Justice James Iredell was so appalled that his colleagues assigned him to ride the Southern Circuit in perpetuity that by his own account he was struck speechless. ${ }^{170} \mathrm{He}$ recovered enough to address a written remonstrance to his brethren: "I will venture to say no Judge can conscientiously undertake to ride the Southern Circuit constantly, and perform the other parts of his duty." ${ }^{171}$ The indignant Iredell, with the help of his brother-in-law Senator Samuel Johnston, persuaded Congress in 1792 to require the justices to rotate circuits. ${ }^{172}$ Several distinguished lawyers declined or resigned appointments to the Court because of the rigors of circuit riding. ${ }^{173}$

The justices reported another problem with circuit riding, one familiar from the English debates in the mid-nineteenth century: the administrative difficulties caused by the desire to prevent a judge from hearing an appeal of a case he had decided below. The Judiciary Act of 1789 specified that district judges, when they sat on circuit courts, should not vote on appeals from cases they had decided below. ${ }^{174}$ There was, however, no similar prohibition on Supreme Court justices hearing appeals of cases they had

\footnotetext{
166. Justices used their charges to grand juries to teach citizens about the federal government and their duties in a republic. 2 The Documentary History of the Supreme Court of the United States, 17891800, at 5-6 (Maeva Marcus et al. eds., 1985); Ralph Lerner, The Supreme Court as Republican Schoolmaster, 1967 SUP. CT. REV. 127.

167. GOEBEL, supra note 150 , at 557.

168. Id. at $569 \&$ n.79.

169. James E. Pfander, Judicial Compensation and the Definition of Judicial Power in the Early Republic, 107 MiCH. L. REV. 1, 23 n.120 (2008).

170. Letter from James Iredell to John Jay et al. (Feb. 11, 1791) in 2 GRIFFITH J. MCREE, LIFE AND CORRESPONDENCE OF JAMES IREDELl 322 (New York, D. Appleton \& Co. 1857) .

171. Id. at 324 .

172. Act of Apr. 13, 1792, c. 21, 1 Stat. 252. On this act, see Pfander, supra note 169, at 28-31.

173. GOEBEL, supra note 150 , at 553-54.

174. Judiciary Act of $1789 \S 4$
} 
decided as circuit judges. ${ }^{175}$ The justices protested to Congress that they sometimes were required to "correct in one capacity the errors which they themselves may have committed in another . . . a distinction unfriendly to impartial justice." 176 To solve this problem, the justices agreed among themselves that they would not vote on appeals from their own decisions except in the case of a split vote. ${ }^{177}$ Critics of the system of circuit riding continued to raise the issue of a justice hearing an appeal from his own decision. ${ }^{178}$

Congress initially was unsympathetic to the justices' plight. The justices were considered to be well-paid compared to state court judges, ${ }^{179}$ partly in order to offset the expense of riding the long circuits. ${ }^{180}$ There was no separate appropriation to cover the justices' travel expenses, and there remained none during the whole period that justices traveled circuit. Failure to reimburse travel expenses, apart from the justices' salaries, hardly encouraged the justices to travel circuit.

In such a large and growing country, regular circuit riding by justices of a central court proved unworkable in any case. Congress gradually diminished the justices' circuit-riding responsibilities. ${ }^{181}$ Also of great importance was the related continuing decay of the circuit court as a panel

175. See Wythe Holt, "To Establish Justice”: Politics, the Judiciary Act of 1789, and the Invention of the Federal Courts, 1989 DuKE L.J. 1421, 1505 (describing the failure of the Act to contain this prohibition).

176. WHEELER \& HARRISON, supra note 165 (quoting Letter from George Washington to Congress (Nov. 7, 1792) in 1 AMERICAN STATE PAPERS MiscellaneOus 51-52 (Washington, Gales \& Seaton 1834)).

177. In Ware v. Hylton, 3 U.S. (3 Dall.) 199, 256 n.* (1796), Justice Iredell explained the practice.

178. In 1861, Senator John P. Hale of New Hampshire gave a floor speech criticizing circuit riding. "I think that the Supreme Court of the United States in its very organization has a radical and fatal error, one that we inherited from the British constitution." Judges should not review their own decisions on appeal, because they "look on those cases as their own children, that they are bound to take care of when they come up to be reviewed on the bench." CONG. GLOBE, 37th Cong., 2d Sess. 26-28 (1861). Hale urged the Senate Judiciary Committee to look abroad, and to "see the judicial progress that some of the best minds of England have been laboring for a long while to accomplish, without effecting a great deal, though they have done something...." Id. at 28 .

179. GOEBEL, supra note 150 , at 568 \& n.71.

180. Pfander, supra note169, at 19-24. Pfander observes that any reduction in circuit riding was in effect a salary increase for the justices, which helps to explain their implacable opposition to riding circuit. Id. at 33-34.

181. In 1793, Congress reduced from two to one the number of justices needed to hold a circuit court. Judiciary Act of 1793, c. 22, 1 Stat. 333. In 1801, the Federalists enacted a law that established six circuits, each with a newly created circuit court judgeship, and ended the Supreme Court justices' circuit riding. Judiciary Act of 1801, c. 4, 2 Stat. 89. The Jeffersonian Republicans quickly repealed the act in 1802 and substituted a new one that abolished the circuit judgeships and again required justices to ride circuit, but retained the six circuits. Judiciary Act of 1802, c. 31, 2 Stat. 156. The Judiciary Act of 1802 assigned to each circuit the Supreme Court justice "residing within" the circuit, the distribution of circuits to be worked out by the justices. Id. $\S \S 4-5$. The circuit courts were to be held by the Supreme Court justice residing within the circuit and the district judge, sitting together as a panel. 
of judges. ${ }^{182}$ Slowly over the nineteenth century, the seeming exception became the rule. More and more, the district judges held circuit court alone. ${ }^{183}$ Not only did this situation leave important questions to be decided by a single judge in the first instance, it diminished the possibility of appeal. In case of a disagreement between two judges sitting together as a circuit court, the point of disagreement was to be stated and certified for decision by the Supreme Court. ${ }^{184}$ If there was only one judge, no disagreement was possible and thus no appeal on that basis.

The situation of the main federal trial court being held by a single judge does not seem so dire to us today; that is a feature of the current federal system. In the nineteenth century, the lack of access to appealcharacteristic of common law systems - made the situation especially dangerous. There was no intermediate court of appeal in the federal system until the end of the nineteenth century. Any appeals from the circuit courts had to go to the Supreme Court, with its limited capacity. Even more important, many cases in the circuit court were not subject to review at all. These included civil matters involving less than $\$ 2,000$, and all criminal cases, except if there was a division of the court. ${ }^{185}$ Federal legislators were concerned. Executive clemency was a remedy, but some viewed it as insufficient to cure the lack of appeal in criminal cases. In 1829, a report of the Senate Judiciary Committee complained of the problem of a single district judge in the circuit court hearing civil cases, ${ }^{186}$ and observed: "The

182. Buried in the Act of 1802 , in the lengthy fourth section, in the middle of a seemingly routine paragraph on the constitution of the sixth circuit, appeared language allowing a circuit court to be held by a district judge sitting alone. $I d$. $\$ 4$ ("provided, that when only one of the judges hereby directed to hold the circuit courts, shall attend, such circuit court may be held by the judge so attending"). The importance of the provision was perhaps not immediately evident. The provision may simply have been intended to cover situations in which the justice for the circuit was unavoidably delayed in travel, or in which a justice or district judge was ill, or had died and had not yet been replaced. This last scenario occurred in the third circuit with the death of Justice William Paterson in 1806, and in 1808 litigants challenged a judgment of the circuit court because it was held by the district judge alone. Chief Justice John Marshall, writing for the Supreme Court, brusquely rejected the challenge based on the provision of the Act. Pollard \& Pickett v. Dwight, 8 U.S. (4 Cranch) 421, 429 (1808).

183. See infra text accompanying notes 186-192. In part, this was because Congress diminished the Supreme Court justices' circuit travel requirements. In 1844, Congress required Supreme Court justices to visit their circuits only once a year, although the circuits had two terms a year. Act of June 17, 1844, c. 96,5 Stat. 676. The growing number of states and expansion of U.S. territory, together with rising caseloads, strained the federal court structure. Congress created new circuits and added a new Supreme Court justice for each. In the process, new states were often left for some time outside a circuit and without a justice, and district judges in those places necessarily exercised the full federal jurisdiction alone.

184. Judiciary Act of 1802, c. $31, \S 6,2$ Stat. 156 .

185. S. Doc. No. 20-50, at 5 (1829). On the lack of review of criminal cases in England, see LANGBEIN, LERNER \& SMITH, supra note 1, at 702-05.

186. S. Doc. No. 20-50, supra note 185 . The report explained that in situations in which a district judge alone holds circuit court, "[h]is single opinion is decisive of the controversy in every matter of law. If the amount exceed two thousand dollars, the party who can sustain the expense of prosecuting an appeal, or writ of error, may indeed have his cause reviewed by the Supreme tribunal—but every suitor 
evil is more striking in criminal cases. The fiat of an individual, which dooms the accused to imprisonment, or to death, is irresistible, irreversible. No appeal is allowed - no writ of error provided by law; and, from the constitution of the Court, no disagreement can arise to invoke the protective interposition of the supreme tribunal." 187

Even Abraham Lincoln's powerful critique of the federal court system in his first annual message to Congress on the state of the union in $1861,{ }^{188}$ together with the creation of circuit judges in $1869,{ }^{189}$ failed to solve adequately the twin problems of single judges presiding over important cases and lack of appellate review. The new circuit judges spent a great deal of time traveling around their large circuits. ${ }^{190}$ In 1889 , the author of a paper presented at the American Bar Association's annual meeting described the circuit judge: "The only thing he can do is to exercise his jurisdiction in a few spots here and there. He wings his flight across a broad expanse and dips down in a few favored localities." 191 The author claimed that at that time, eight-ninths of the cases in the circuit courts were disposed of by single judges, mostly district judges. ${ }^{192}$

Federal caseloads and backlogs continued to grow. Not only were the population and commercial activity increasing, but after the Civil War Congress greatly expanded federal jurisdiction. In 1875, Congress passed two important and related statutes within two days of each other: the Civil Rights Act $^{193}$ and the Judiciary Act. ${ }^{194}$ The latter fulfilled the Federalist dream of granting general federal question jurisdiction to the federal trial courts. With these acts, the Republicans helped realize their goals of full

cannot sustain this expense, and to him the doom is final. In many instances, too, the counsels of an Associate would probably have changed the result, and have rendered this appeal unnecessary; and in those cases, where, from the smallness of the amount in controversy, the right of appeal is not allowed, the injury resulting from the error of this single Judge, is remediless." Id.

187. Id.

188. In his first annual message to Congress on the state of the union in 1861, President Lincolnalthough he had other issues to discuss - thought it important to observe that "the country generally has outgrown our present judicial system" and to propose solutions. Message to Congress of Dec. 3, 1861, in 5 The Works of ABRAHAM Lincoln 41 (Roy P. Basler ed., 1953). He explained that the circuit system as originally designed no longer functioned adequately, and that eight recently admitted states had never had circuit courts attended by Supreme Court justices. Id. at 41-42. His recommendations included limiting the number of Supreme Court justices, regardless of the number of circuits, and then adding separate circuit judges. $I d$. at 42.

189. Congress created nine circuit judgeships, one for each circuit. In the same act, Congress reduced the requirement of Supreme Court justices visiting their circuits to once every two years. Act of Apr. 10, 1869, c. 22, 16 Stat. 44. On the passage of this act, see Glick, supra note 164, at 1815-1817.

190. ERwin C. Surrency, History of the Federal Courts 62-63 (2d ed. 2002). The circuit judges spent time hearing appeals from the district courts in admiralty cases, appointing receivers in equity cases, and appointing other judges to serve for district judges who were ill or incapacitated. Id.

191. Walter B. Hill, The Federal Judicial System, 12 A.B.A. Rep. 289, 302 (1889).

192. Id. at 304 .

193. Act of Mar. 1, 1875, c. 114, 18 Stat. 335.

194. Act of Mar. 3, 1875, c. 137, 18 Stat. 470. 
rights of citizenship for freedmen and a robust national market with unified legal rules. As a result, however, in the late nineteenth century the federal courts became clogged, and appeals in particular slowed tremendously. Appeals brought to the Supreme Court took years to decide. Decisions of federal trial courts were often for practical purposes unreviewable. ${ }^{195}$ The appellate docket of the Supreme Court, which was mandatory, became so crowded that justices sometimes determined they could not travel their circuits. ${ }^{196}$ By the $1880 \mathrm{~s}$, several justices refused to travel their circuits altogether. ${ }^{197}$

There were sharply differing opinions about how to solve the problem, echoing the earlier debates over the federal judiciary between Federalists and Anti-Federalists. Some, particularly well-represented in the Senate, wanted to preserve the expanded federal jurisdiction and to speed up the administration of justice in the federal courts by creating an intermediate court of appeals with separate personnel. ${ }^{198}$ They worried about prejudice against corporations in state courts and the safety of capital, which they viewed as threatened by populist enactments of state legislatures. ${ }^{199}$ Others, with strength in the House of Representatives and the South and West, opposed the creation of an intermediate court of appeals and wanted to restrict federal jurisdiction instead. ${ }^{200}$ In their view, the expansion of federal jurisdiction after the Civil War was anomalous and should be reversed. They complained that the federal courts favored commercial interests and were too willing to overturn state laws. ${ }^{201}$

A significant concern of advocates for an intermediate court of appeals was the problems caused by single district judges holding circuit courts. The lack of review, or effective review, led to a potential "judicial

\footnotetext{
195. WHEELER \& HARRISON, supra note 165 , at 16.

196. Glick, supra note 164, at 1818.

197. Id. at 1824. Congress's consistent failure to appropriate money for the justices' travel expenses on circuit remained a reason for justices to avoid the duty when they could. Some justices and other federal judges accepted free railroad passes, presumably for this reason, although railroads were frequent litigants in federal courts. See id. at 1814-15; 6 Charles Fairman, History of the SUPREME COURT OF THE UNITED STATES 541-48 (1971).

198. Felix FrankFurTER \& JAMES LANDIS, THE BusinESS OF THE SUPREME COURT 91-92 (1928); Daniel S. Holt, The Abolition of Federal Circuit Courts and the Course of Judicial Reform in the Early Twentieth Century 7 (Mar. 2011) (unpublished paper) (on file with the author); Howard Gillman, How Political Parties Can Use the Courts to Advance Their Agendas: Federal Courts in the United States, 1875-1891, 96 AM. PoL. SCI. REV. 511 (2002). Proponents of intermediate courts of appeals argued that a panel of judges on appeal could take the place of a panel of judges in the first instance. George W. McCrary, Needs of the Federal Judiciary, 13 CENT. L.J. 167 (1881) [hereinafter McCrary, Needs of the Federal Judiciary]. The key was to prevent a decision by a single judge which was effectively unreviewable, leading to a "judicial despotism." George W. McCrary, Our Federal Judiciary, 2 CENT. L.J. 551 (1875) [hereinafter McCrary, Our Federal Judiciary].

199. FRANKFURTER \& LANDIS, supra note 198, at 91-92.

200. Id. at 82-85; Holt, supra note 198; Gillman, supra note 198, at 520.

201. FRANKFURTER \& LANDIS, supra note 198, at 85.
} 
despotism." 202 A circuit judge, formerly a member of the House of Representatives who had called for creation of an intermediate court of appeals, emphasized in an article in 1881 that circuit courts had been established on the principle that important classes of cases were to be decided by panels of judges. He stressed the importance of deciding questions of law, but his argument also applied to questions of fact. He explained:

The value of discussion, and a comparison of views by judges in conference, can hardly be overestimated. The Federal judicial system is based upon the theory that the concurrence of two judges in the judgment of the circuit courts in important cases is desirable; or that in case of a difference of opinion, while the view of the presiding judge shall prevail, the case . . may go to the Supreme Court. $^{203}$

\section{Judicial Comment: Broad Discretion in the First Hundred Years}

In the early nineteenth century, decisions of the Supreme Court gave trial courts - which often at the time included the justices themselveslarge discretion to comment on facts to the jury. The Court declared that it would not even review such questions on writ of error, virtually the only form of appeal allowed. Justice Joseph Story authored many of the early opinions. ${ }^{204}$ Story did urge trial judges to take care to separate the law from the facts, and to make sure that the jury understood that the latter were for them to decide. ${ }^{205}$ Otherwise, the Supreme Court left the matter to the trial judges' discretion.

In several of the cases, Story expressed impatience with the growing practice of counsel to put the whole charge of the trial court to the jury on the record, and to object to every part of it. ${ }^{206}$ The Court announced its "decided disapprobation" of the practice, and declared it to be

\footnotetext{
202. McCrary, Our Federal Judiciary, supra note 198, at 551.

203. McCrary, Needs of the Federal Judiciary, supra note 198, at 169.

204. See, e.g., McLanahan v. Universal Ins. Co., 26 U.S. (1 Pet.) 170, 182 (1828) (Story, J.) ("It is, doubtless, within the province of a Court, in the exercise of its discretion, to sum up the facts in the case to the jury, and submit them, with the inferences of law deducible therefrom, to the free judgment of the jury."); Carver v. Jackson ex rel. Astor, 29 U.S. (4 Pet.) 1, 4 (1830) (Story, J.); Magniac v. Thomson, 32 U.S. (7 Pet.) 348, 390 (1833) (Story, J.); see also Tracy v. Swartwout, 35 U.S. (10 Pet.) 80, 95-96 (1836) (McLean, J.); Games v. Stiles ex rel. Dunn, 39 U.S. (14 Pet.) 322, 327 (1840) (McLean, J.).

205. McLanahan, 26 U.S. (1 Pet.) at 182 (reversing a judgment in which the trial court instructed the jury "'that upon the whole evidence in the case' the plaintiffs are not entitled to recover, and the verdict of the jury 'ought to be for the defendants"').

206. Carver, 29 U.S. (4 Pet.) at 4; Magniac, 32 U.S. (7 Pet.) at 390.
} 
"unauthorized" and "extremely inconvenient both to the inferior and to the appellate court." 207 The reason was that the trial judge's charge often included observations on matters of fact. Story firmly declared, "With the charge of the court to the jury, upon mere matters of fact, and with its commentaries upon the weight of the evidence, this court has nothing to do. ${ }^{~} 208$ If the trial court gave a misdirection on a matter of law, that was different, and could properly be pointed out and objected to. ${ }^{209}$ The Supreme Court, however, would not trammel the trial court's commentary on matters of fact, so long as the issue was left to the jury. ${ }^{210}$ Story suggested that the possibility of such comments being reviewed was greater in England, because of the practice there of reviewing a motion for a new trial before the full court. ${ }^{211}$ In the federal courts, in contrast, motions for new trial were addressed to the trial court only and could not be reviewed by the Supreme Court on writ of error. ${ }^{212}$

The Supreme Court repeatedly declared, through the late nineteenth century, that it would not review a trial judge's comments on fact. ${ }^{213}$ The most ringing statement of this rule came in 1886, probably inspired by the growing gulf in practice between the state and federal courts:

In the courts of the United States, as in those of England, from which our practice was derived, the judge, in submitting a case to the jury, may, at his discretion, whenever he thinks it necessary to assist them in arriving at a just conclusion, comment upon the evidence, call their attention to parts of it which he thinks

207. Carver, 29 U.S. (4 Pet.) at 4; accord Magniac, 32 U.S. (7 Pet.) at 390.

208. Carver, 29 U.S. (4 Pet.) at 4 ("Observations of that nature are understood to be addressed to the jury, merely for their consideration, as the ultimate judges of matters of fact; and are entitled to no more weight or importance, than the jury in the exercise of their own judgment choose to give them. They neither are, nor are they understood to be, binding upon them, as the true and conclusive exposition of the evidence."); accord Magniac, 32 U.S. (7 Pet.) at 390.

209. Carver, 29 U.S. (4 Pet.) at 4.

210. Chief Justice Taney described a limited exception in a case in 1857: A trial judge could not charge a jury "upon a supposed or conjectural state of facts, of which no evidence has been offered." United States v. Breitling, 61 U.S. (20 How.) 252, 254-55 (1857). In that case, the trial court, at the request of defendant's counsel, charged the jury that they should find for the defendant if, at the time defendant signed a bond, it was understood that other persons would sign the bond as obligors, but they did not. The Supreme Court found there was no evidence that other persons were supposed to sign the bond. Id. at 253, 255. Such a charge, the Court stated, "does not aid them [the jurors] in coming to correct conclusions, but its tendency is to embarrass and mislead them. It may induce them to indulge in conjectures, instead of weighing the testimony." Id. at 255. See also Michigan Ins. Bank v. Eldred, 76 U.S. (9 Wall.) 544, 553-54 (1869) (following Breitling). For several further examples of federal judges commenting on evidence, see Woolhandler \& Collins, supra note 30, at 646 n.235, 647 n.243.

211. McLanahan, 26 U.S. (1 Pet.) at 189-91.

212. Indianapolis \& St. Louis R.R. Co. v. Horst, 93 U.S. 291, 301 (1876) (citing cases).

213. See, e.g., Transp. Line v. Hope, 95 U.S. 297, 302 (1877) (“An expression of opinion simply by a judge upon a question of fact is not a ground of error.") (citing New York cases); Vicksburg \& M.R. Co. v. Putnam, 118 U.S. 545, 553-54 (1886). 
important, and express his opinion upon the facts; and the expression of such an opinion, when no rule of law is incorrectly stated, and all matters of fact are ultimately submitted to the determination of the jury, cannot be reviewed on writ of error. ${ }^{214}$

\section{The Effects of Differing State Practices}

During the course of the nineteenth century, the practice of judicial comment on evidence in federal and state courts increasingly diverged. As I and other scholars have described, many states limited or prohibited the trial judge's power to comment. ${ }^{215}$ During the first half of the nineteenth century, the Supreme Court did not mention different state practices with respect to summing up or comment on evidence. The Court cited English cases - particularly those of Lord Mansfield — and New York cases. ${ }^{216}$ New York had a robust practice of judicial comment on evidence.

After mid-century, the Court began to take more notice of differences. In the 1851 case Mitchell v. Harmony, Chief Justice Roger Taney, a Jacksonian Democrat when he went on the Court and a supporter of states' rights, observed that, in some of the states, judges did not sum up or comment on evidence. ${ }^{217}$ Most of the states at the time continued to follow "the usages of the English courts of justice," in which the judge always summed up the evidence and could comment on it. He refused to declare which practice was preferable, but recommended that federal courts follow the practice of the state in which they sat. ${ }^{218} \mathrm{He}$ cited Story's opinions, and the Court upheld the trial judge's comments in the case, which were made when the circuit court was sitting in New York. ${ }^{219}$

The question of differing state court practices grew more intense after 1872, with the passage of the federal Conformity Act. ${ }^{220}$ As explained previously, the Process Act of 1792 required federal trial courts to follow the forms and modes of proceeding of the state in which they sat, as the

214. Vicksburg, 118 U.S. at 553. In Vicksburg, the federal Circuit Court in Georgia commented on evidence in a manner unfavorable to the defendant, a railroad in a personal injury case. See also United States v. Philadelphia \& R.R. Co., 123 U.S. 113, 114 (1887) (paraphrasing and citing Vicksburg); Rucker v. Wheeler, 127 U.S. 85, 93 (1888) (quoting Vicksburg); Lovejoy v. United States, 128 U.S. 171, 173 (1888) (citing Rucker); California Ins. Co. v. Union Compress Co., 133 U.S. 387, 417 (1890); Simmons v. United States, 142 U.S. 148, 155 (1891).

215. See supra notes 28-30.

216. See, e.g., McLanahan, 26 U.S. (1 Pet.) at 189-91 (citing opinions by Mansfield and James

Kent).

217. Mitchell v. Harmony, 54 U.S. (13 How.) 115, 130-31 (1851).

218. Id. at 131 .

219. Id. at 130 ("This mode of charging the jury has always prevailed in the State of New York, and has been followed in the Circuit Court ever since the adoption of the Constitution.").

220. Act of June 1, 1872, c. 255, 17 Stat. 196. 
practices existed in 1792. The federal courts adhered to traditional common law pleadings and practice. With the advent in many states of codes of civil procedure simplifying pleading and merging law and equity, the bar was faced with the necessity of learning two different systems of pleading to practice in both federal and state courts. To prevent this difficulty, Congress enacted the Conformity Act, specifying that "the practice, pleadings, and forms and modes of proceeding" in federal trial courts in civil cases, other than equity and admiralty cases, "shall conform as near as may be" to those of state courts in the state in which they sat. ${ }^{221}$

The Court was soon faced with the question whether, under the Conformity Act, federal trial courts had to follow state rules prohibiting judicial summing up or comment on evidence. In 1875, months after the enactment of the Civil Rights Act and the Judiciary Act, as Republicans were expanding federal jurisdiction and seeking a strong national judiciary, the Court gave a powerful answer. ${ }^{222}$ "The personal conduct and administration of the judge in the discharge of his separate functions" was not a practice, pleading, form, or mode of proceeding under the Act. ${ }^{223}$ The Act was simply intended to have the federal courts follow the code pleading of the states in which they sat, when practicable. The Act did not require federal trial judges to follow state laws limiting their power to comment on evidence. The Court's opinion went further and suggested it might not be possible for Congress to limit the trial judge's power to comment, even if that was its intent. If the legislature had tried to limit the judge in this respect, "the powers of the judge, as defined by the common law, were largely trenched upon." 224 The Court warned, "There are certain powers inherent in the judicial office." 225 These stern statements were far from the more state-centered views of the Court in the 1850s. In the 1870s, the Supreme Court made it possible for federal courts to assert control over juries, and by extension, counsel.

At the same time as the justices were confirming the power of federal trial judges to comment on evidence under the Conformity Act, they were strengthening the ability of those judges to engage in an extreme form of

\footnotetext{
221. Id. § 5; see Bellia \& Clark, supra note 155, at 655-56; Nudd v. Burrows, 91 U.S. 426, 441 (1875).

222. Nudd, 91 U.S. at 441-42.

223. Id. at 442. Citing Nudd v. Burrows, the Court the next year rejected a demand that the federal trial court administer special interrogatories to a jury after a general verdict, following state law. Horst, 93 U.S. at 299-301. In Horst, the demand was made by counsel for the defendant, a railroad, in a personal injury case involving allegations of contributory negligence. The Court's decisions concerning the Conformity Act did not always favor railroads. See also St. Louis, I. M. \& S. Ry. Co. v. Vickers, 122 U.S. 360, 363 (1887) (citing Nudd in holding that state law cannot prohibit a federal judge from commenting on evidence)

224. Nudd, 91 U.S. at 442.

225. Id.
} 
comment: directed verdict. In a previous article, I discussed growing use of the directed verdict procedure in the nineteenth century to combat the perceived bias of juries, and to promote predictability in the law. ${ }^{226}$ The Supreme Court emphasized the need for federal trial judges to control juries: "It is the duty of the court in relation to the jury to protect parties from unjust verdicts arising from ignorance of the rules of law and of evidence, from impulse of passion or prejudice, or from any other violation of his lawful rights in the conduct of a trial." ${ }^{, 227}$ Directed verdicts spared the necessity of the expensive and time-consuming remedy of new trial. ${ }^{228}$ Comment on evidence, many hoped, would have some of the same benefits as directed verdict, in a broader range of cases. ${ }^{229}$

Personal injury cases brought against railroads or manufacturers raised special concerns about jury bias. ${ }^{230}$ The practices in federal courts gave judges considerably more control over juries than in most state courts. Although directed verdict and comment on evidence often worked in favor of defendant railroads and manufacturers, federal trial judges also used their powers of judicial comment in favor of plaintiffs. The Supreme Court consistently held that such comments were unreviewable. ${ }^{231}$

By 1887, the Court was defining the constitutional phrase "trial by jury" to mean a trial in which the judge could comment on evidence if he chose. ${ }^{232}$ In United States v. Philadelphia \& Railroad Co., the Court upheld the trial judge's instruction to the jury that "while the court does not desire to control your finding, but submits the question to you, it is of the opinion that you should not, under the circumstances, find for the plaintiff."233 The Court continued this constitutional definition in later cases, in stronger terms. ${ }^{234}$ In 1930 the Supreme Court declared that the phrase "trial by jury"

226. Lerner, Directed Verdict, supra note 24, at 488-89.

227. Pleasants v. Fant, 89 U.S. (22 Wall.) 116, 121 (1874) (upholding a directed verdict).

228. Lerner, Directed Verdict, supra note 24, at 489.

229. For a justification of comment on evidence based on the need for a trial judge to consider a motion for a new trial because of a verdict against the evidence, see Consequa v. Willings, 6 F. Cas. 336, 337 (C.C.D. Pa. 1816) (No. 3128).

230. Lerner, Directed Verdict, supra note 24 at 486-89.

231. See, e.g., Vicksburg, 118 U.S. at 553-54 (declaring unreviewable the trial judge's comments to the jury giving his opinion that the defendant railroad was negligent in maintaining tracks).

232. "Trial by jury in the courts of the United States is a trial presided over by a judge, with authority, not only to rule on objections to evidence, and to instruct the jury upon the law, but also, when in his judgment the due administration of justice requires it, to aid the jury by explaining and commenting upon the testimony, and even giving them his opinion upon questions of fact." Philadelphia \& R.R. Co., 123 U.S. at 114.

233. Id. at 117.

234. Capitol Traction Co. v. Hof, 174 U.S. 1, 13-14 (1899) (“Trial by jury' in the primary and usual sense of the term at the common law and in the American constitutions . . . is a trial by a jury of 12 men in the presence and under the superintendence of a judge empowered to instruct them on the law and advise them on the facts...."). 
meant jury trial as understood and applied at common law, which required, among other things, "that the trial should be in the presence and under the superintendence of a judge having power to instruct them [the jury] as to the law and advise them in respect of the facts." 235 These elements, the Court announced, were beyond the power of the legislature to alter. ${ }^{236}$ The trial judge's power to comment on evidence was an essential element of jury trial under both the Sixth and Seventh Amendments. ${ }^{237}$

\section{B. Review of Capital Cases in the Supreme Court: 1889}

In 1889, as the number of judgments of circuit courts held by single judges grew, Congress acted to help redress the problem of a lack of appeal in criminal cases. ${ }^{238}$ The 1889 Act altered the jurisdiction of certain courts. Most important, under the Act, the Supreme Court could review federal convictions for capital crimes. ${ }^{239}$

\section{Judge Isaac Parker and the Origins of the 1889 Act}

Congress had long been concerned about a lack of review in criminal cases. The provision of the 1889 Act, however, was specially motivated by anxiety about — even hostility toward - a particular judge, together with questions about jurisdiction in Indian Territory and Indian policy. These concerns were closely related to appellate control of judicial comment on evidence, as will be seen later in the discussion of cases in the Supreme Court from the Western District of Arkansas.

The provision of the 1889 Act was passed in part to control a single judge: the federal district judge for the Western District of Arkansas, Isaac Parker (1838-1896). ${ }^{240}$ The Western District of Arkansas had an unusual jurisdiction which included large parts of the Indian Territory, in what is now Oklahoma. The federal courts for this area had jurisdiction over

235. Patton v. United States, 281 U.S. 276, 289 (1930) (holding that a criminal defendant may waive the right to a 12-person jury where one of the jurors is excused because of illness during the trial).

236. Id. at 290. "These common law elements are embedded in the constitutional provisions above quoted, and are beyond the authority of the legislative department to destroy or abridge." Id.

237. Bute v. Illinois, 333 U.S. 640, 650 n.4 (1948)

238. Act of Feb. 6, 1889, c. 113, 25 Stat. 655 ("An act to abolish circuit court powers of certain district courts of the United States, and to provide for writs of error in capital cases, and for other purposes.").

239. Id. $\$ 6$.

240. Parker is hardly an obscure figure in the literature of the American West. He has been the subject of a half dozen biographies. For a historiography of Parker, see ROGER H. TULLER, "LET NO GUILTY MAN ESCAPE": A JUdiCIAL BIOGRAPHY OF "HANGING JUdGE” ISAAC C. PARKER 3-9 (2001). Parker is, however, not well-known in the federal courts literature, and his role in provoking restrictions on comment in federal courts has been overlooked. 
crimes committed by or against non-Indians in the Indian Territory. ${ }^{241}$ (According to treaties, Indian tribal courts had jurisdiction over crimes committed by Indians against Indians. ${ }^{242}$ )

Isaac Parker began his judgeship in circumstances that were, to put it mildly, difficult. His immediate predecessor as district judge was William Story, a corrupt and incompetent hack. Story had freed condemned prisoners on bond pending execution. ${ }^{243}$ In 1874 , Story resigned to avoid impeachment for taking bribes. ${ }^{244}$ Many perceived the Indian Territory as a place where law was not enforced, especially during the tenure of Judge Story, and the area attracted and nurtured notorious gangs and outlaws. The lack of effective extradition laws caused fugitives from justice to flock there. ${ }^{245}$ Murders, robberies, rapes, and horse thefts were commonplace. ${ }^{246}$ It was popularly known as "Robbers' Roost" and the "Land of the SixShooter.",247

In May 1875, Isaac Parker arrived at Fort Smith, Arkansas as the new district judge. He had served as a Missouri state judge and a U.S. Congressman for Missouri. While in Congress, he had championed Indians' rights and become known as "the Indians' best friend." $248 \mathrm{He}$ was determined to create order and respect for law in the Indian Territory. On September 3, 1875, six persons he had sentenced to death - three whites, two Indians, and a black-were hanged at once, all for murder. The

241. Act of June 30,1834 , c. $161, \S 1,4$ Stat. 729,729 (the 1834 Trade and Intercourse Act). In 1790 , in the Trade and Intercourse Act, Congress extended the criminal jurisdiction of federal courts to U.S. citizens in "Indian Country," including Indian Territory. Act of July 22, 1790, c. $33, \S \S 5$ \& 6, 1 Stat. 137, 138. In 1817, Congress enacted a statute that became known as the Federal Enclaves Act, which extended federal jurisdiction over Indians who committed crimes against non-Indians. 18 U.S.C. $\$ 1152$ (2016). This provision was codified in the 1834 Trade and Intercourse Act, supra. I thank Gregory Ablavsky for this information. In 1851, the new Western District of Arkansas was given jurisdiction over part of the Indian Territory. Act of Mar. 3, 1851, c. 23, 9 Stat. 594.

242. In 1885, Congress enacted the General Crimes Act, 23 Stat. 385, which extended federal jurisdiction to certain major crimes committed by Indians against Indians in Indian country. The statute was prompted by concerns about the actions of a Sioux tribal court in a murder case, permitted to stand by the Supreme Court in Ex Parte Crow Dog, 109 U.S. 556 (1883). See Sidney L. Harring, Crow DOG's CASE 129-141 (1994).

243. TULLER, supra note 240, at 63 .

244. GLENN SHIRLEy, LAW WeST OF FORT SMith 16-17 (1968)

245. TULLER, supra note 240, at 47-48; SHIRLEY, supra note 244, at 21.

246. The editor of Fort Smith's Western Independent despaired. "We have lived in and around the Indian country since the spring of 1834 , but have never known such a state of terror. Now it is murder throughout the length and breadth of the Indian country. It has been the rendezvous of the vile and wicked from everywhere, an inviting field for murder and robbery .... Stealing horses is an everyday occurrence, and murder and robbery seem equal to that sin. It is dangerous to travel alone where villains from four quarters of the United States congregate to murder, rob and steal." Editorial, WESTERN INDEPENDENT (Fort Smith), Aug. 28, 1873, quoted in SHIRLEY, supra note 244, at 23.

247. SHIRLEY, supra note 244 , at 24 .

248. TULLER, supra note 240, at 34-41; SHIRLEY, supra note 244, at 27-28. 
morning of the executions, over 5,000 persons packed the jail yard. ${ }^{249}$ The executions attracted national attention and unfavorable coverage in the press in other parts of the country. A reporter for Fort Smith's Western Independent expressed the local view: The men died because "they are preying wolves upon the lives and property of their fellow beings, unfit to live and unsafe to remain at large," a fact which "should not be lost in the excitement and glare of the terrible exhibition." ${ }^{" 250}$ Parker's effectiveness and incorruptibility won enthusiastic support from the local press, even from papers initially skeptical of him. ${ }^{251}$

A crucial element of Parker's law enforcement efforts were the deputy marshals. During Parker's tenure on the bench, about 200 deputy marshals were appointed, of whom around 40 or 50 served at a given time. The deputies were tasked with policing and arrests. ${ }^{252}$ At the end of his life, Parker stated that during his time as a judge, 65 of the deputy marshals in his district were killed performing their duties. ${ }^{253}$ Parker seems to have understated the carnage; modern scholarly estimates range from 75 to 100 deputy marshals killed in the district during that time. ${ }^{254}$ It is difficult to understand what motivated so many men to take such a dangerous job. The deputies seem to have taken pride in being one of "the men who rode for Parker." ${ }^{255}$ Evading arrest in the Indian Territory was an elaborate and frequent activity, known as "scouting." "56 Gangs often had elaborate lookout systems for deputy marshals. Adding to the difficulty of arresting violent criminals, gangs had often so intimidated the population that many ordinary persons helped to conceal fugitives and impeded deputy marshals. ${ }^{257}$ Parker persevered, with the help of the deputies, and more executions followed. ${ }^{258}$ In many the of murder trials Parker presided over, the victim was a deputy marshal. As will be seen, Parker commented

\footnotetext{
249. SHIRLEY, supra note 244, at 35-40; TULLER, supra note 240, at 53.

250. Report of J.W. Weaver, quoted in SHIRLEY, supra note 244, at 40.

251. SHIRLEY, supra note 244 , at 62 .

252. The movie "True Grit," starring John Wayne in the 1969 version, and Jeff Bridges in the 2010 version, is thought to be based on the activities of Henry "Heck" Thomas, a U.S. deputy marshal during Parker's tenure.

253. SHIRLEY, supra note 244, at 47.

254. Michael J. Brodhead, IsaAC C. Parker: Federal Justice on the Frontier 42 (2003) [hereinafter BRODHEAD, PARKER].

255. BRODHEAD, PARKER supra note 254. Another motivation may have been the illegal advantage deputy marshals took in staking out claims before the official opening of the Unassigned Lands in Indian Territory to settlement. See William W. Howard, The Rush to Oklahoma, HARPER's WEEKLY, May 18, 1889, at 391-92.

256. Supreme Court opinions concerning appeals from Judge Parker's court refer to the practice of "scouting." See, e.g., Hicks v. United States, 150 U.S. 442, 444 (1893); Hickory v. United States, 160 U.S. 408, 411 (1896).

257. SHIRLEY, supra note 244 , at $41-64$.

258. TULLER, supra note 240, at 63-64; SHIRLEY, supra note 244, at 61-62.
} 
powerfully to juries about the need to deter killers of deputy marshals, comments which drew the disapproval of the Supreme Court.

Parker's actions drew attention to the lack of appeals to federal courts in criminal cases. He also incurred the hostility of members of Congress who wanted to open the Indian Territory to more settlement. Parker opposed non-Indian expansion into the Indian Territory and supported the titles of the tribes and the jurisdiction of tribal courts. ${ }^{259}$ The possibility of opening the Unassigned Lands-lands that had not been assigned to any tribe-in Indian Territory to non-Indian settlement had long been a contentious political issue. The law reformers and expansionists together succeeded in passing the Act of 1889. Parker was clearly a trigger. Both sponsors of the bill, Senator James K. Jones and Representative John Rogers, represented Arkansas. Senator George Vest of Missouri, an enthusiastic supporter of non-Indian settlement in Indian Territory, singled out Parker in a speech in favor of the bill. Vest argued that Parker had executed men for years "without any right to ask the Supreme Court of the United States whether it be judicial murder or not." ${ }^{\text {260 }}$ Less than a month after the act was signed providing appeals in capital cases to the U.S. Supreme Court, President Grover Cleveland signed an act permitting nonIndian settlement in the Unassigned Lands in Indian Territory beginning at a specific date and time. ${ }^{261}$ The Oklahoma land rush, an extraordinary episode in American history, accordingly started at noon on April 22, $1889 .^{262}$

With the arrival of appeals in criminal cases to the Supreme Court, Parker's practices of addressing juries came under judicial scrutiny. The result was a significant change in rules concerning judicial comment on evidence.

\section{Change in Review of Judicial Comment}

It was the advent of review of criminal cases - at a time when almost no justices traveled circuit and heard trials any longer-that undid the rule that the Supreme Court would not consider a trial court's comments on evidence. To my knowledge, scholars have not discussed this change, nor the role that Isaac Parker played in provoking it. For only a few years, between 1889 and 1897, the Supreme Court regularly heard first appeals of

\footnotetext{
259. SHIRLEY, supra note 244 , at $140-41$.

260. 19 CONG. REC. 5611 (1888).

261. Indian Appropriations Act of 1889, c. 412, 25 Stat. 980 (signed March 2, 1889).

262. Harper's Weekly published a fascinating account. "Unlike Rome, the city of Guthrie [Oklahoma] was built in a day. To be strictly accurate in the matter, it might be said that it was built in an afternoon. At twelve o'clock on Monday, April 22d, the resident population of Guthrie was nothing; before sundown it was at least ten thousand." Howard, supra note 255, at 391.
} 
capital murder cases. Prior to that, the Court essentially only heard a criminal appeal if there was a division in the trial court. After that, the Court routinely heard cases of tax fraud, drug distribution, and regulatory crimes - and those mostly already heard in the circuit courts of appeals. The unusual eight years strongly marked the practice of the federal courts concerning judicial comment on evidence.

Early in this period, the Supreme Court suggested that the Court would extend to criminal cases the rule about not reviewing a trial judge's comments on evidence. In a criminal case in 1891, the court applied the longstanding rule that it would not review judicial comments on fact. ${ }^{263}$ That was a case of embezzlement from a bank.

Over the next few years, however, the Supreme Court decided a mass of cases on review from the Western District of Arkansas and Judge Isaac Parker. The cases from the Western District of Arkansas were not cases of embezzlement from a bank. They were murders: capital cases. The stakes were high, and the Court emphasized this. In these cases, the Court fundamentally changed its method of review, and thoroughly examined Parker's statements to the jury on fact for undue influence. These cases from the 1890s were cited repeatedly in later opinions of the Supreme Court and of the circuit courts of appeal in overturning verdicts.

Isaac Parker was "a verdict-getting judge." ${ }^{264}$ To many, he exemplified the dangers of the single judge with unchecked power. He viewed himself as primarily responsible for maintaining law and order in his district, especially in the Indian Territory. He thought certainty of punishment was more important in deterring crime than severity, and declared at the end of his life that he would be happy to abolish the death penalty if crime received more certain and swift punishment. ${ }^{265} \mathrm{He}$ worked hard to maintain a group of deputy marshals to do dangerous jobs and to take great risks, and he wanted to make sure the deputies were rewarded by prompt trials of the persons they arrested, "with a large percentage of convictions."266

263. Simmons v. United States, 142 U.S. 148, 172-73 (1891) (citing Vicksburg in a criminal case for embezzlement). In that case, the trial court had told the jury that "he regarded the testimony [against the defendant] as convincing." Id. at 172 .

264. The phrase is taken from New York lawyer Theron Strong and his description of New York judge George C. Barrett. THERON G. STRONG, LANDMARKS OF A LAWYER's LIFETIME 103 (1914).

265. Isaac C. Parker, interview in St. Louis Republic, Sept. 6, 1896, at 6, quoted in TULLER, supra note 240 , at 156 .

266. Harry P. Daily, Judge Isaac C. Parker, 11 Chrons. OF OKLA. (1933). On the dangers to the deputy marshals, see supra text accompanying notes 252-257. The deputy marshals were paid primarily for the arrest of wanted men, and were ineligible to receive federal rewards. The federal deputies could, however, and often did, collect rewards from state and local authorities, private persons, and railroads and other transportation companies. Parker frequently complained of the low official pay of the deputies, and wrote to Congress to try to get higher pay for them. Parker explained that the costs to deputy marshals were higher in the Indian Territories than in more settled parts of the country, in which law enforcement could count on the support of the local population. SHIRLEY, supra note 244, at 46. 
Parker's charges to the jury in criminal cases were vigorous, often lasting an hour and a half, ${ }^{267}$ sometimes quoting the Bible and using the language of moral condemnation. In one case in which a defendant fled following a killing, Judge Parker commented to the jury by reading several passages from the Bible, including the story of Cain's murder of Abel and a verse from Proverbs: "The wicked flee when no man pursueth." 268 The inhabitants of his district were varied and polyglot; over 30 tribes coexisted in the Indian Territory, and there were also whites and blacks, and many of mixed ancestry. Parker believed it necessary to explain basic principles of law and treaties to juries in the area and to give detailed guidance in his lengthy charges. Parker responded vigorously to his critics: "I have been accused of leading juries. I tell you a jury should be led . . . if they are guided they will render justice." ${ }^{269}$ Parker worked to ensure that jurors were properly paid for their service, and he expressed his gratitude for their undertaking the inconvenience and burdens. ${ }^{270}$ Henry Starr-a halfCherokee gang leader who was twice convicted of murder in Parker's court and went on to a lucrative career as a bank robber after the Supreme Court reversed his convictions - had a different opinion of these jurors. Starr, however, agreed about Parker's influence: "Arkansas is noted for ignorance and Hill-Billyism, and fifty percent of the jurymen were drawn from backwoods counties and were completely dominated by the powerful personality of Judge Parker.",271

It is possible that Parker was reacting in his charges to the newly aggressive defense lawyers who had begun to practice in his court. The most effective of these was J. Warren Reed, a West Virginian who arrived in Fort Smith in $1889^{272}$ and soon discovered the value of an appeal to the Supreme Court. He was the first defense counsel to appeal a murder conviction from Parker to the Supreme Court, and he won a reversal in $1891{ }^{273} \mathrm{He}$ also aggressively applied to the President for executive clemency. Other lawyers rapidly joined Reed as news of his success spread. ${ }^{274}$ Because of Parker's activities, there was a ready supply of clients waiting at the jail.

\footnotetext{
267. TULLER, supra note 240, at 147. The Supreme Court, in reviewing one of Parker's charges, commented that it took up twenty pages of the printed record. Hickory, 160 U.S. at 409.

268. Hickory, 160 U.S. at 415-16.

269. Isaac C. Parker, interview in St. Louis Republic, Sept. 6, 1896, at 6, quoted in TULLER, supra note 240 , at 156 .

270. BRODHEAD, PARKER, supra note 254, at 50-51.

271. Id. at 51 .

272. SHIRLEY, supra note 244, at 147.

273. Alexander v. United States, 138 U.S. 353 (1891).

274. SHIRLEY, supra note 244, at 155.
} 
Between 1889 and 1897, 49 criminal cases from Parker's court were appealed to the Supreme Court, almost all convictions for capital murder. ${ }^{275}$ Of these 49, the Supreme Court affirmed 13 and reversed $36 .{ }^{276}$ Sometimes the Court reversed a particular defendant's conviction multiple times. Several reversals were noteworthy for the Supreme Court's treatment of Parker's comments on evidence to the jury.

In 1893, on appeal from Judge Parker, the Court reversed a conviction in part on the ground of judicial comments on fact. ${ }^{277}$ Some knowledge of the facts is necessary to understand the judicial comments and reversal. In Hicks v. United States, Hicks, a Cherokee, was tried for aiding and abetting the murder of a white man, Colvard. At the time Colvard was killed, Hicks and Rowe, another Cherokee, were evading U.S. marshals who had warrants for their arrest. Hicks and Rowe were armed to resist arrest. ${ }^{278}$ Hicks and Rowe seem to have suspected Colvard was trying to apprehend them, and Rowe shot and killed him. (Rowe was later killed by deputy marshals trying to arrest him.) At Hicks's trial, several witnesses testified that Hicks had made statements at the time of the killing suggesting that he expected and encouraged Rowe to shoot Colvard, and that after Rowe did so, the two rode off together. ${ }^{279}$ Hicks testified that he had tried to persuade Rowe not to shoot Colvard. ${ }^{280}$

Parker told the jury that they should consider Hicks's interest in the case in deciding whether his testimony was true. ${ }^{281}$ The Supreme Court was concerned that a judge's adverse comment on defendant's testimony would in effect take from him the ability to testify on his own behalf. Congress had given criminal defendants the right to testify under oath in federal court

275. Westlaw search. For proceedings begun after September 1, 1896, Congress ended direct review of criminal cases from the Indian Territory by the Supreme Court, and provided appeals in lower courts. Act of Mar. 1, 1895, c. 145, 28 Stat. 693 (providing for a special court of appeal for criminal cases in the Indian Territory, composed of three district judges, with a further appeal to the circuit court of appeal).

276. Six of the reversals were on motion or confession of error of the Solicitor General. Davenport v. United States, 163 U.S. 682 (1896); Goldsby v. United States, 163 U.S. 688 (1896); Luckey v. United States, 163 U.S. 692 (1896); King v. United States, 164 U.S. 701 (1896); Thornton v. United States, 163 U.S. 707 (1896); Kettenring v. United States, 168 U.S. 703 (1897).

277. Hicks, 150 U.S. at $450-53$.

278. Id. at 444 .

279. Id. at 445-46.

280. Id. at 446

281. Parker said, "You are to consider [defendant's] interest in this case, you are to consider his consequent motive growing out of that interest, in passing upon the truthfulness or falsity of his statement. He is in an attitude, of course, where any of us, if so situated, would have a large interest in the result of the case; the largest, perhaps, we could have under any circumstances in life; and such an interest, consequently, as might cause us to make statements to influence a jury in passing upon our case that would not be governed by the truth. We might be led away from the truth because of our desire. Therefore it is but right, and it is your duty, to view the statements of such a witness in the light of his attitude and in the light of other evidence." $I d$. at 451. 
in $1878 .{ }^{282}$ In Hicks, the Court stated that the defendant's privilege to testify on his own behalf "would be a vain one if the judge, to whose lightest word the jury, properly enough, give a great weight, should intimate that the dreadful condition in which the accused finds himself should deprive his testimony of probability. . . . The policy of this enactment should not be defeated by hostile comments of the trial judge, whose duty it is to give reasonable effect and force to the law." 283 The Court believed such adverse comment was especially problematic because it viewed the evidence against the defendant as weak. ${ }^{284}$ Judicial comment on defendant's testimony continued to be a point of special concern for appellate courts, including later cases in the Supreme Court reversing Judge Parker. ${ }^{285}$

In Hicks, Justice David Brewer, with Justice Henry Brown dissented strongly, arguing that the Court should adhere to the longstanding rule that a judgment would not be reversed because of a judge's comments on fact. ${ }^{286}$ Brewer rejected the idea that the judge had to be especially careful about comment on the defendant's testimony: "The statute makes the defendant a competent witness. It affirms nothing as to his credibility."287 Brewer, like his English counterparts, was concerned about the use of appeals in criminal cases to reverse convictions on technical grounds. ${ }^{288}$

In later cases of appeals from Judge Parker, the Court admonished Parker for his general tone of "indignation." In Starr v. United States, Henry Starr shot to death a deputy marshal who was trying to arrest him on a warrant for horse theft. ${ }^{289}$ Starr claimed he had shot the deputy in selfdefense. On appeal, Chief Justice Fuller observed that the "circumstances

\footnotetext{
282. Act of Mar. 16, 1878, c. 37, 20 Stat. 30.

283. Hicks, 150 U.S. at 452.

284. Id.

285. See Allison v. United States, 160 U.S. 203, 209-10 (1895) (reversing murder conviction for Judge Parker's improper comment on defendant's testimony); Hickory, 160 U.S. at 424-25 (reversing murder conviction for killing a deputy marshal trying to arrest defendant for Judge Parker's improper comment on defendant's testimony). In Allison, the Court was also concerned that Parker's summing up did not discuss testimony about a fact favorable to the accused, which was not contradicted. "Justice and the law demanded that, so far as reference was made to the evidence, that which was favorable to the accused should not be excluded." Allison, 160 U.S. at 212.

286. Hicks, 150 U.S. at 453-60. Brewer, Brown, and Rufus Peckham were frequent dissenters in reversals of convictions on appeal from Judge Parker. See, e.g., Hickory v. United States, 151 U.S. 303, 317 (1894)

287. Id. at 459 .

288. Tuller, supra note 240, at 154; Michael J. BrodHEAD, DAVID J. BReWER: THE LifE OF A SUPREME COURT JUSTICE, 1837-1910, at 111-13 (1994) [hereinafter BRODHEAD, BREWER]. Brewer's antipathy toward crime and criminals arose partly from his strong Christian beliefs (he was the son of New England missionaries), and partly from his experiences as a young lawyer and judge in the new state of Kansas in the early1860s. BRODHEAD, BREWER, supra, at 1-3, 11-12. Brodhead has called Brewer "Parker's only consistent friend on the Supreme Court." Id. at 111-12.

289. Starr v. United States, 153 U.S. 614, 615 (1894).
} 
of this case apparently aroused the indignation of the learned judge in an uncommon degree." ${ }^{, 290}$ Parker had expressed himself strongly to the jury on the subject of dangers to deputy marshals. He told the jury, "Without these officers, what is the use of this court? It takes men who are brave to enforce the law here. . . [T] here is no protection unless the law is upheld by men of this kind ...." ${ }^{291}$ Fuller expressed the Court's "disapprobation" of these comments and denied that different methods of instructing a jury might be appropriate in different areas of the country. "Whatever special necessity for enforcing the law in all its rigor there may be in a particular quarter of the country," the rules and manner of the administration of justice should be the same everywhere, and "argumentative matter of this sort should not be thrown into the scales by the judicial officer who holds them." $" 292$

Relations between the Supreme Court and Judge Parker escalated into a forensic battle. In 1895, the infamous gang leader Cherokee Bill (whose real name was Crawford Goldsby) killed the jailer at Fort Smith while in jail awaiting review by the Supreme Court of his conviction for a previous murder. Parker pointedly criticized the Supreme Court in a statement to a newspaper in St. Louis, where he was visiting relatives. ${ }^{293}$ He asked why, when crime generally was decreasing in the Indian Territories, murder had increased. He attributed the rise in murders to reversals of convictions by the Supreme Court. ${ }^{294}$ These reversals undermined the swiftness and certainty of punishment that he-like the English judges-thought so important to deterrence. ${ }^{295}$ "First, the convicted murderer has a long breathing spell before his case comes before the Supreme Court; then, when it does come before that body, the conviction may be quashed; and wherever it is quashed it is always upon the flimsiest technicalities. The Supreme Court never touches the merits of the case."296

Parker attributed the Supreme Court's reversals to the lack of experience of most of the justices with criminal cases. He referred to the justices' inexperience with criminal cases repeatedly, most notably in an interview with a reporter shortly before his death: "The justices are men

290. Id. at 626. Fuller continued, "and that indignation was expressed in terms which were not consistent with due regard to the right and duty of the jury to exercise an independent judgment in the premises, or with the circumspection and caution which should characterize judicial utterances." $I d$.

291. Parker continued: "You are to stand by the nation. You are to say to all the people that no man can trample upon the law, wickedly, violently, and ruthlessly; that it must be upheld if it has been violated." Id. at 627.

292. Id. at 627-28.

293. Isaac C. Parker, statement to the Globe-Democrat (St. Louis), July 30, 1895, at 9, quoted in SHIRLEY, supra note 244, at 156.

294. Id.

295. Id.

296. Id. at $156-57$. 
from civil walks of life; it is not then surprising that they are liable to err in criminal cases." 297 Such inexperienced persons were apt to "utterly forget the hardened character of the criminals I have to deal with," to forget the family the convict made fatherless. ${ }^{298}$

The Court, in Starr and in other cases, remarked on the youth of the defendants; ${ }^{299}$ Starr was 18 when he shot the deputy marshal. ${ }^{300}$ After shooting the deputy marshal and before he was arrested seven months later, Starr used his new notoriety to organize a well-known gang which committed a string of robberies and horse thefts. ${ }^{301}$ The Court's reversal of his conviction spared Starr from hanging; on retrial, a jury convicted Starr again, and again the Supreme Court reversed the conviction for Parker's instructions to the jury on how to weigh the flight of the accused. ${ }^{302}$

An important point of difference between the opinions for the Court and for the dissent concerned beliefs about the effect of judicial comment on the jury. Different views on this subject permeated debates about comment on evidence, among courts and commentators. In Hicks, the Court stated that the jury gave the judge's "lightest word . . . great weight." ${ }^{303}$ In contrast, Brewer credited the jury with independence of thought. ${ }^{304}$ Earlier, in 1851, Chief Justice Roger Taney had pointed out an apparent contradiction in the argument of those who supported restrictions on judicial comment. Taney denied that the trial court's comments would have "an undue and improper influence" on the jury's minds and decision. ${ }^{305} \mathrm{He}$ observed that such an objection "questions their intelligence and independence, qualities which cannot be brought into doubt without

297. Isaac C. Parker, interview in St. Louis Republic, Sept. 6, 1896, at 6, quoted in TulLER, supra note 240 , at 156 .

298. Id.

299. See, e.g., Allison, 160 U.S. at 203 (defendant was about 20 years old at the time of the killing);

Hickory, 160 U.S. at 409 (defendant was 19 years old at the time of the killing).

300. Starr, 153 U.S. at 615

301. SHIRLEY, supra note 244 , at $175-80$.

302. Starr v. United States, 164 U.S. 627, 631-32 (1897); see also Hickory, 160 U.S. at 414-23. After Starr was convicted for murder a third time before a different judge and was serving a sentence in prison, President Theodore Roosevelt pardoned hin in 1903 because of his role in encouraging the surrender of his fellow inmate, Crawford Goldsby ("Cherokee Bill"), during an attempted jailbreak in 1895. See BRODHEAD, PARKER, supra note 254 , at 159 . On the attempted jailbreak, see supra text accompanying note 293. Following the reversals of his murder convictions and the pardon, Henry Starr went on to a lucrative career as a bank robber. BRODHEAD, PARKER, supra note 254 , at 159 . He is thought to have robbed at least 21 banks. A silent movie was made about him, released in 1919, called "A Debtor to the Law." In the movie, Henry Starr played himself. Id. at 187. In 1921, at the age of 46, Starr was shot fatally while robbing a bank. Id. at 159.

303. Hicks, 150 U.S. at 452.

304. Id. at 459 ("Is it not clear that they [the jurors] would understand simply that their attention was called to the effect on his [defendant's] credibility of a contradiction between his testimony and that of disinterested witnesses?").

305. Mitchell v. Harmony, 54 U.S. (13 How.) 115, 131 (1851). 
taking from that tribunal the confidence and respect which so justly belong to it, in questions of fact." 306 In the late twentieth century, Judge Jack Weinstein expressed the same opinion. ${ }^{307}$

\section{Creation of an Intermediate Court of Appeals: 1891}

\section{The Evarts Act}

For many years, the battles between the House and Senate discussed above prevented federal legislation addressing the structure of the courts. In 1891, the stalemate broke and Congress passed the Circuit Court of Appeals Act, ${ }^{308}$ known as the Evarts Act, creating an intermediate court of appeals. William Evarts, an eminent lawyer and Republican senator from New York who was chairman of the Senate Judiciary Committee, was mainly responsible for the act. ${ }^{309}$

The sittings of the new circuit courts of appeal were to be held by three-judge panels, with two judges constituting a quorum. ${ }^{310}$ On these panels were eligible to sit the circuit judges of the circuit (now two per circuit), district judges of the circuit, and the Supreme Court justice assigned to the circuit. ${ }^{311}$ The Act reduced the mandatory appellate jurisdiction of the Supreme Court in civil cases and made many cases reviewable there only by certification of the circuit court of appeals or by writ of certiorari. ${ }^{312}$ The justices got immediate relief, with a drop in their caseload. ${ }^{313}$ The drop in review of civil cases more than compensated for an increase in criminal appeals. The Evarts Act made convictions in any "capital or otherwise infamous crime" directly appealable from the trial court to the Supreme Court. ${ }^{314}$

Under the Evarts Act, the district courts became the primary trial courts, but the old circuit courts were not abolished. The maintenance of the circuit courts as trial courts was a critical concession. Evarts himself regarded it as important to bring appellate judges "in contact with the

\footnotetext{
306. Id.

307. Weinstein, supra note 5, at 163. For a contrary view, see Saltzburg, supra note 7, at 39-40.

308. Act of Mar. 3, 1891, c. 517, 26 Stat. 826.

309. Chester L. Barrows, William M. Evarts: Lawyer, Diplomat, Statesman 480-83

(1941); Brainerd Dyer, The Public Career of William M. Evarts 257-60 (1933, republished 1969). Evarts became convinced of the necessity of an intermediate court of appeals partly because of the persistent complaints and assiduous cultivation of Chief Justice Melville Fuller. Glick, supra note 164 , at $1824-26$.

310. Act of Mar. 3, 1891, § 2 .

311. Id. § 3 .

312. Id. $\S \S 5,6$

313. FRANKFURTER \& LANDIS, supra note 198, at 102.

314. Act of Mar. 3, 1891, § 5 .
} 
profession and the suitors and the people in the courts of first instance as frequently as possible." 315 Some Democrats were willing to support the measure because circuit judges would continue to preside over jury trials and "intermingle with the people." 316 Apparently it was enough for the circuit judges, rather than the Supreme Court justices, to hear trials. Although the Evarts Act did not entirely end circuit riding by justices, most justices gave it up at that point. ${ }^{317}$

The compromise of maintaining the circuit trial courts was undone because of the old problem of making sure that judges did not hear appeals of cases they had decided below, combined with a new sense of strict hierarchy in the federal courts. A district judge sometimes needed to sit on the appellate court when a circuit judge had to recuse himself because of having presided in the circuit trial court. This situation was not only an administrative nuisance, but offended the growing sense of judicial hierarchy. A report of the House Judiciary Committee in 1890 favored abolishing the circuit trials courts in order to create a pure and distinct three-tiered system. Abolition of the circuit trial courts and creation of an intermediate court "secures the absolute independence ... of the three classes of courts, to wit, district, circuit, and Supreme." ${ }^{318}$ Commentators even compared the federal judiciary to the officer corps of the army, the epitome of hierarchy: "It looks odd to see an inferior judge reverse his superior - a captain reversing his general's orders!"319

The growing sense of hierarchy in the federal courts echoed the systematizing and increasingly strict hierarchy that railroads had adopted in the late nineteenth century for their legal counsel. Railroads were the first corporations to develop clear chains of command for legal services, in order to handle the mass of litigation that railroads were constantly involved in. ${ }^{320}$ The railroads usually used a three-tiered structure of general counsel, division counsel (responsible for a group of states), and local attorneys. ${ }^{321}$ This organization resembled the three-tiered structure recommended for the federal courts. Many prominent lawyers in the late nineteenth century-including both Lincoln and Evarts-had worked extensively for railroads as either in-house counsel or outside counsel. These lawyers were therefore increasingly used to hierarchies within the

\footnotetext{
315. 21 CONG. REC. 10,222 (1891) (statement of Senator William Evarts of New York).

316. Id. at 10,231 (statement of Senator John T. Morgan of Alabama). On support for appellate judges also hearing trials, see Holt, supra note 198, at 8.

317. Glick, supra note 164 , at 1829.

318. H. Comm. on the Judiciary, Jurisdiction of United States Courts, H. Rep. No. 1295 (1890), quoted in Holt, supra note 198, at 7.

319. Henry Wollman, The Danger of the Federal Judiciary, N. AM. REV., Mar. 1895, at 379.

320. LANGBEIN, LERNER \& SMITH, supra note 1, at 1021, 1023.

321. Id. at 1023 .
} 
legal profession. Former and current railroad lawyers vigorously asserted the need for judicial hierarchy in order to manage swelling caseloads. ${ }^{322}$

Although some representatives still argued for appellate judges mingling with the people and making sure justice was done in the trial courts, ${ }^{323}$ theirs was a losing cause. In 1911, Congress abolished the old circuit courts and killed the justices' circuit riding. ${ }^{324}$ In the federal courts, trial judges and appellate judges were now distinct. Despite their equally secure tenure, trial and appellate judges were increasingly viewed as markedly different.

\section{Later Cases in the Supreme Court Concerning Comment on Evidence}

After 1911, the Supreme Court mostly got out of the business of reviewing trial judges' comments to juries. That job went to the circuit courts of appeal instead. We have seen that the Evarts Act in 1891 caused most appeals in civil cases to go to the circuit courts of appeal, while appeals in criminal cases went directly to the Supreme Court. After that, Congress transferred criminal appeals to the circuit courts of appeal in two stages. In 1897, Congress restricted review by the Supreme Court directly from the trial court to capital cases. Other convictions went to the circuit courts of appeal for review. ${ }^{325}$ In 1911, Congress eliminated direct review of capital convictions by the Supreme Court; all criminal convictions were reviewable in the circuit court of appeals. ${ }^{326}$ The Supreme Court got almost complete control of its docket in $1925 .^{327}$

Once the justices could pick which issues to decide, judicial comment on evidence was rarely among them. Policing the comments of trial courts was left mainly to the circuit courts. A later stage of this research will examine the practices of the different circuits and regional variation among them, together with the frequency and strength of comment in the trial courts over time. The circuit courts of appeals frequently cited the opinions

322. At the 1897 American Bar Association conference, former railroad lawyer James H. Raymond argued that "the whole idea of a Court of Appeals is absolutely in its very integrity destroyed when any officer . . . of that court also performs duty in an inferior court." 1897 American Bar Association Conference, at 62.

323. Holt, supra note 198, at 12-13.

324. Act of Mar. 3, 1911, c. 231, 36 Stat. 1087. The Judiciary Act of 1925 removed the Supreme Court further from ordinary cases, by making most of its docket discretionary. Act of Feb. 13, 1925, c. 229, 43 Stat. 936. Writs of certiorari replaced mandatory appeals to the Court for almost all cases.

325. Act of Jan. 20, 1897, c. 68, 29 Stat. 492.

326. Act of Mar. 3, 1911, c. 231, § 5, 36 Stat. 1087, 1088.

327. Act of Feb. 13, 1925, c. 229, 43 Stat. 936. 
of the Supreme Court reversing Judge Parker for his comments on evidence. ${ }^{328}$

In a civil case in 1913, Justice Holmes expressed impatience about "what seem to us meticulous objections to every detail in the conduct of the trial," and the Court upheld the trial court's comments. ${ }^{329}$

In criminal cases, the Court occasionally overturned convictions, relying heavily on previous opinions reversing Judge Parker. Chief Justice Charles Evans Hughes wrote the opinion in the leading modern case, Quercia v. United States, ${ }^{330}$ in 1933. Hughes explained that federal trial judges have the power to comment on evidence, and quoted Matthew Hale's description of the practice's value. ${ }^{331} \mathrm{He}$ then warned that the "privilege of the judge to comment on the facts has its inherent limitations. His discretion is not arbitrary and uncontrolled, but judicial . . . . His privilege of comment in order to give appropriate assistance to the jury is too important to be left without safeguards against abuses." 332 There followed a long string of descriptions of the holdings of the Court's cases reversing Judge Parker, with citations. ${ }^{333}$

In Quercia, a Narcotic Act case, the trial judge had observed the defendant wiping his hands during his testimony and commented to the jury that "that is almost always an indication of lying." 334 The First Circuit had upheld the conviction. The Supreme Court condemned the trial judge's "sweeping denunciation" and did not doubt that it was "highly prejudicial." This error was not cured by the trial court's statement that his opinion of the evidence was not binding on the jury, the Court held, citing the reversal of Judge Parker in Starr v. United States. ${ }^{335}$ Quercia is cited in almost

328. See, e.g., Mullen v. United States, 106 F. 892, 895 (6th Cir. 1901) (reversing conviction and citing Starr, Hickory, and Allison); Oppenheim v. United States, 241 F. 625, 629 (2d Cir. 1917) (reversing conviction and citing Starr, Allison, and Hicks); Weare v. United States, 1 F.2d 617, 618 (8th Cir. 1924) (reversing conviction and citing Starr and Hickory); O'Shaughnessy v. United States, 17 F.2d 225, 228 (5th Cir. 1927) (reversing conviction and citing Starr and Hickory); Malaga v. United States, 57 F.2d 822, 827 (1st Cir. 1932) (reversing conviction and citing Starr, Hickory, Allison, and Hicks).

329. Graham v. United States, 231 U.S. 474, 480 (1913). The judge charged the jury "that it was 'not a case for sentimental considerations of any kind,' with more in the same direction." Id. at 481.

330. 289 U.S. 466 (1933).

331. Quercia, 289 U.S. at 469 (quoting HALE, supra note 42, at 291-92).

332. Id. at 470 .

333. Id. at 470-71 (citing Hicks, Starr, Allison, and Hickory). The Court also acknowledged the growing importance of the circuit courts of appeal in this area. Hughes described a rule that had developed in the courts of appeal: When no testimony had been offered as to the previous character of the accused, it was prejudicial error for the trial court to comment unfavorably on his general character. $I d$. at 471 (citing cases from the courts of appeals).

334. Id. at 468. "Why that should be so we don't know, but that is the fact. I think that every single word that man said, except when he agreed with the Government's testimony, was a lie." Id.

335. Id. at 472 (citing Starr, 289 U.S. at 472). 
every decision by the courts of appeals concerning judicial comment on evidence.

The Supreme Court swooped in once again in 1933, the same year as Quercia, with the last significant opinion on comment on evidence. ${ }^{336}$ The defendant was convicted of refusing to supply information concerning his income tax returns. The trial court told the jury his opinion that the defendant was guilty beyond a reasonable doubt. ${ }^{337}$ The Seventh Circuit had reversed. The Court declared that, "[a]lthough the power of the judge to express an opinion as to the guilt of the defendant exists," it should be exercised "cautiously" and "only in exceptional cases." ${ }^{\text {"338 }}$ Essentially, the Court suggested, that power should only be used in cases in which the facts were undisputed, and the current case was not one of those. ${ }^{339}$

\section{CONCLUSION}

In the early twentieth century, legal commentators in the United States remarked on a decline in the importance of jury trial. A prominent New York state judge and other writers had called for the end of jury trial in civil cases. ${ }^{340}$

Several authors at this time claimed that the only way to save jury trial from terminal decline was to revive the power of trial judges to comment on evidence. John Henry Wigmore wrote that the loss of judicial power to comment on evidence "has done more than any other one thing to impair the general efficiency of jury trial as an instrument of justice." ${ }^{341}$ If the power were restored, he predicted "[a] new birth of long life will then be open for the great and beneficent institution of Trial by Jury." ${ }^{342}$

\footnotetext{
336. United States v. Murdock, 290 U.S. 389 (1933).

337. Id. at 393 ("So far as the facts are concerned in this case, Gentlemen of the Jury, I want to instruct you that whatever the Court may say as to the facts, is only the Court's view. You are at liberty to entirely disregard it. The Court feels from the evidence in this case, that the Government has sustained the burden cast upon it by the law and has proved that this defendant is guilty in manner and form as charged beyond a reasonable doubt.").

338. Id. at 394 .

339. Id. (citing Horning v. District of Columbia, 254 U.S. 135 (1920)). Justices Stone and Cardozo dissented without opinion. Id. at 398 .

340. Joseph M. Proskauer, A New Professional Psychology Essential for Law Reform, 14 A.B.A. J. 121, 123-24 (1928) (recommending abolition of jury trial in contract cases); George M. Hogan, The Strangled Judge, 14 J. AM. JUdiCATURE SOC'Y 116, 116-17 \& n.1 (1930) (describing and citing many articles).

341. 5 John H. Wigmore, A Treatise on the Anglo-American System of Evidence in TRIALS AT COMMON LAW 557, § 2551 (2d ed. 1923).

342. Id. See also Hogan, supra note 340, at 117 (arguing that the public was getting impatient with "the jury trial where the presiding judge is present but takes no part; . . . where opposing counsel stage a game of emotional prejudice; . . . where juries are bewildered; and where justice miscarries" and claiming that these problems would be solved by allowing trial judges the power to comment on evidence).
} 
This article suggests that a return to robust powers to comment is unlikely, even with relatively competent trial judges with secure tenure. The creation of appellate courts with separate personnel, especially for criminal appeals, significantly limits the discretion of trial courts in commenting on evidence. Even English trial judges, with their considerable prestige and long professional experience, have been restricted. They sum up the evidence, and the summing up may be influential, but comment less often than formerly.

The problem of how to guide or to control the jury turns out to be virtually intractable. Strong judicial powers to comment invite the question of why the legal system should use juries at all. In England in the nineteenth century, judicial domination of verdicts through comment caused the virtual elimination of civil jury trial. Prominent commentators have suggested that potent judicial influence likewise calls into question the continuation of the criminal jury. ${ }^{343}$ If juries are used, strong judicial powers to comment may be abused, and constitute yet another ground of appeal based on procedure, rather than the merits of a judgment. If, on the other hand, judges do not comment, juries are left to their own devices in resolving issues of fact, and are subject to confusion and bias caused by counsel in the adversary system.

343. WiLLIAMS, supra note 85, at 307-08. Williams attributed the comparative success of the English jury, relative to its American counterpart, to "the fact that our system of summing up enables the judge to give the jury a lead, which the jury follow sufficiently often to give an appearance of reliability to the mode of trial." Id. at 307 . He further observed: "It need hardly be pointed out that this explanation of the jury's success is not one that yields any very strong argument for a continuation of the system." Id. 